\title{
The Effects of School Competition on Academic Achievement and Grading Standards
}

\author{
OLIVER HIMMLER
}

CESIFO WORKING PAPER No. 2676

CATEGORY 5: ECONOMICS OF EDUCATION

JUNE 2009
An electronic version of the paper may be downloaded
- from the SSRN website:
www.SSRN.com
- from the RePEc website:
- from the CESifo website:
www.RePEc.org
www.CESifo-group.org/wp




\title{
The Effects of School Competition on Academic Achievement and Grading Standards
}

\begin{abstract}
Nationwide school choice and fixed per-student governmental funding provide incentives for Dutch schools to perform well. Roughly one third of Dutch pre-university schools are of catholic denomination. Acknowledging this widely available outside option to public and other schools, this paper considers the effect of catholic competition on non-catholic school performance in pre-university education. Employing data from central exit exams, a positive link between competition intensity and academic achievement is found. In addition to raising achievement, higher levels of competition are not associated with a deterioration of grading standards. Finally, (inverse) quantile regression estimates show no evidence of schools at the bottom of the achievement distribution being hurt by competition.
\end{abstract}

JEL Code: I21.

Keywords: education, competition, Netherlands, IVQR.

\author{
Oliver Himmler \\ Goettingen University \\ Department of Economics \\ Platz der Goettinger Sieben 3 \\ 37073 Goettingen \\ Germany \\ ohimmler@uni-goettingen.de
}

Jan 2007, revised Mar 2009

Funding by the Deutsche Forschungsgemeinschaft in the priority programme 1142 "Institutional Design of Federal Systems: Theory and Empirical Evidence" is gratefully acknowledged. I would like to thank participants of the 2007 IIPF Annual Congress and the 5th CESifo Norwegian-German Seminar for their insightful comments. I thank Fabiënne Plieschke for her assistance in obtaining the data. 


\section{Introduction}

It is by no means a new discovery that there may be beneficial effects of competition in the market for education. Ever since Friedman (1955), economists have argued that school choice in the form of vouchers would exert competitive pressure on school authorities which in turn would lead them to provide higher school quality. On the downside, increased choice could induce increased sorting by ability. This cream-skimming by the better schools is often thought to leave the least able students amongst themselves. In addition to being stuck in a bad school, they may thus be robbed of any positive peer effects they may have experienced in a mixed-ability school.

There is rather extensive empirical evidence on the effects of school competition in North America, yet this is not the case in Europe. Given the substantial institutional differences between the US and many European countries, further research is in order. This paper fills this gap by considering the Dutch education system which is characterized by centrally devised and graded school exit examinations and fixed per-student funding through the central government. In combination with unrestricted school choice which has been in place ever since the early 20th century, this constitutes a system of nationwide quasi-vouchers. Even though increasing interventions of the central government when it comes to curricula and the size of teaching staff are sometimes criticized (Walford, 2000), this institutional setup clearly complies with conceptions of a competitive school system harbored by proponents of school choice. It thus makes for an interesting subject for studying the implications of school competition.

\subsection{The Link between School Quality and Competition}

In the United States, each year a substantial share of the population relocates and secondary education is traditionally funded to a considerable degree by means of local property taxes. This makes educational policies and their effects on households' locational decisions a standard example of Tiebout's (1956) 'voting with the feet'. Indeed, research has shown that households take school quality into account when choosing their place of residence and they are willing to pay a premium for it, i.e. school quality is capitalized in house prices. ${ }^{1}$

Whether school quality reacts to parents exercising the exit-option (or the threat thereof) has been at the center of another strand of research. Predominantly, school quality is measured in terms of academic achievement - i.e. test scores and graduation rates ${ }^{2}-$ and the main explanatory variable is the intensity of competition in the relevant market. One

\footnotetext{
${ }^{1}$ Obviously, in a larger geographical context, there are many other variables such as job availability which influence residential patterns. Within a metro area, however, school quality has been shown to be closely linked to house prices. See Black (1999), Weimer and Wolkoff (2001), Barrow (2002) and Bayer, Ferreira and McMillan (2005). For evidence that these effects can also be found outside the United States, see Cheshire and Sheppard (2003).

${ }^{2}$ Whether grades and the likes are a good measure of school quality is disputable. While certainly an intriguing issue, the discussion is beyond the focus of this paper.
} 
reasonable indicator of competition would be the number of schools or school districts that make up the choice set within a particular market. Alternatively, the Herfindahl index of concentration, which is closely related to the number of schools or districts can be used (Martinez-Vazquez and Seaman 1985, Hoxby 2000). The percentage of students attending private schools (Hoxby 1994) or the number of private schools is also often employed, as these schools provide an outside option to public schools which may be too similar to actually impose competitive pressure upon one another. Evidently, these measures are all the more powerful when education markets are clearly defined geographically, thus determining a household's choice set.

When employing competition measures, endogeneity issues need to be taken into account. Picture a school district whose schools perform poorly. This district will be especially prone to the initiation of private schooling, as there are more students who are unhappy with the school they presently attend and this will add to the demand for alternatives. Failure to acknowledge this mechanism may lead to an underestimation of the impact of choice on achievement, as one may concurrently observe high degrees of competition and low public school quality. In a similar fashion, the number of school districts may be a function of school quality. Even though the endogeneity of competition has recently been contested by Brasington (2005) and Rothstein (2007), at least testing for endogeneity is necessary.

Empirical Evidence for the United States. Even though school choice continues to be promoted as a means of ensuring that students receive a better education and voucher programs are introduced or extended in the United States, the scientific evidence on the effects of competition are far from being unambiguous. Using data from the UTD Texas School Project, Hanushek and Rivkin (2003) define metropolitan areas as education markets. Competition is measured by a Herfindahl index, which shows no significant connection to school quality. Marlow (1999) on the other hand finds a positive impact on achievement in many of his specifications, when competition is operationalized through the use of a county-wide Herfindahl index. Earlier, Marlow (1997) had already stated positive effects of the number of available schools per student on SAT scores using state-level data. ${ }^{3}$ Studies by Borland and Howsen (1993) and Zanzig (1997) only find effects up to a certain threshold level of competition. Geller, Sjoquist and Walker (2006) cannot identify a significant positive influence of competition by private schools on test scores in Georgia at all.

Most prominent in the public discourse are probably two studies by Hoxby $(1994,2000)$. In the more recent paper she develops an index of competition based on the number of school districts in a metropolitan area. The use of streams as an instrumental variable for the number of districts leads her to the conclusion of a positive influence of choice on achievement. The earlier study also finds a positive effect, measuring competition as the percentage of students in the market attending private schools. Here, the instruments are the shares of the population associated with various religious denominations. An approach

\footnotetext{
${ }^{3}$ Schools per student or per capita is not a reasonable concept of competition when local education markets are studied. Simply imagine a local education market which harbors few students or is sparsely populated but has only one school. This would imply high levels of competition when in fact the school is a local monopolist.
} 
similar to Hoxby (1994) is used by Dee (1998), Jepsen (1999) and Sander (1999). Even though all three studies allow for endogeneity of competition, only Dee finds a significant positive link to levels of achievement. This lack of consensus in the literature is best summarized in an extensive survey of studies on school choice by Belfield and Levin (2002), who state that a mere third of the 25 empirical studies considered in their survey find significantly positive effects of levels of competition on academic achievement.

Empirical Evidence for Other Countries. Possibly due to the assumption that Tiebout-sorting is less prevalent in Europe, a large portion of the literature is concerned with North America. Moreover, in a European context, education isn't typically funded via local taxes, pointing to lower levels of Tiebout-style competition. However, there are countries such as the Netherlands, which allow for school choice without changing residential location, i.e. these countries do not set up mandatory catchment areas. When the institutional feature of nationwide school choice is combined with fixed per-student governmental funding, the setup corresponds to an unrestricted nationwide system of school vouchers. A voucher system compares favorably to traditional Tiebout competition, as it enables low-income families who otherwise wouldn't be able to afford living in a good school district to exercise the exit-option. It provides a level playing field when it comes to making educational choices, at least on a financial level.

Åhlin (2003) as well as Sandström and Bergström (2005) state that the abolition of catchment areas in Sweden and the installation of a voucher scheme in 1992 led to positive effects on achievement. Beneficial effects are also found by Bradley, Johnes and Millington (1999) for the United Kingdom. They define competition as the number of schools in the education market. Using urban density as a proxy for school competition, Gibbons and Silva (2006) find that students in densely populated areas in the UK fare better academically. When it comes to the Netherlands, the research on school choice has been largely descriptive (Patrinos 2000, De Vijlder 2000, Ritzen et al. 1997, and Dronkers 1995). Levin (2004) and Dronkers (2004) examine the effect of attending a catholic school on academic performance. Both studies conclude that catholic schools generate superior educational outcomes. Clearly, this does not say anything about the impact of levels of competition on achievement. We should, however, take these results as ample evidence that the real outside option to attending a non-catholic school in the Netherlands is transferring to a catholic school rather than choosing another non-catholic one.

Given that the US evidence - which is inconclusive in any event - may not apply to education systems in other countries and the rather thin literature on school choice in Europe, this paper adds an important piece to the school choice puzzle. The remainder of the paper is organized as follows: section 2 explains in further detail the motivation for choosing the Netherlands as an object of examination. Data sources are described in section 3, along with the general empirical strategy. Section 4 contains the main empirical results. Beneficial effects of competition on academic achievement are found and neither various robustness checks nor the 2SLS estimations suggest any differently. Section 5 uses quantile regression (QR) and inverse/instrumental variable quantile regression methods (IVQR) in order to determine whether anyone is hurt by school competition, despite the positive effects that mean regression suggests. Section 6 concludes. 


\section{The Dutch Education System}

In this section, a brief overview of the different types of schools in the Netherlands, the organization of school leaving examinations and centralized funding is given.

\section{$2.1 \quad$ Types of secondary schools}

Dutch compulsory education encompasses twelve school years and starts with primary education (Basisschool) at age five. Primary education lasts eight years and is in most cases completed with the taking of the CITO (Central Institute for Test Development) End of Primary School Test, a standardized test supposed to help parents determine the type of secondary education most suitable for their child.

Today, there are three types (opleidingen) of institutions in secondary education (Voortgezet Onderwijs, VO) among which parents may choose:

(i) Pre-vocational or middle level secondary education (Voorbereidend middelbaar beroepsonderwijs, $V M B O$ ) lasts four school years.

(ii) Senior or higher general secondary education (Hoger Algemeen Voortgezet Onderwijs, $H A V O)$ amounts to five years of schooling.

(iii) Pre-university education (Voorbereidend Wetenschappelijk Onderwijs, VWO) encompasses six years of schooling and offers a choice of either the "Atheneum", where neither Greek nor Latin is compulsory, or the "Gymnasium" which has obligatory Greek and Latin lessons. The goal of $V W O$ education is to enable students to take up a university education; it is thus the highest form of secondary education in the Dutch education landscape.

Most Dutch schools offer more than one of these opleidingen, and often one school will provide access to all three kinds of secondary education. The analysis in this paper is restricted to the pre-university branch, because it is assumed that parents and students in higher branches make more use of the freedom to choose. ${ }^{4}$

\subsection{Mandatory School Leaving Exams}

Dutch students end their secondary schooling careers with the taking of central examinations. These central exams (centraal examen) account for half the final grade. The

\footnotetext{
${ }^{4}$ Denessen, Sleegers and Smit (2005) find that with higher socioeconomic status, proximity as a reason for a particular school choice becomes less important. Since the share of students from a lower status background is lower in VWO than in other branches, this implies that in VWO more so than in other branches parents will not just pick the school that is geographically most convenient.
} 
other half is determined via decentralised testing (schoolexamen). The centraal examen are centrally arranged and graded by the testing agency CITO. ${ }^{5}$ All students of the same opleiding are faced with identical questions and grading is done by $C I T O$ within 4 weeks' time. An official body, appointed by the Ministry of Education, CEVO (Centrale examencommissie vaststelling opgaven) establishes the norms for the central exams. ${ }^{6}$

\subsection{School Choice and Centralized Funding}

The demand side of the Dutch secondary education system is characterized by parents enjoying unrestricted nationwide school choice. There are no catchment areas whatsoever and schools can neither charge tuition nor easily decline students based on criteria such as ability, thus leaving (at least theoretically) little room for cream-skimming.

Market entry barriers on the supply side are also low, as everyone in the Netherlands is granted the right to set up a school, if he or she so desires. The Dutch government is obliged to take care of school funding as soon as the number of enrolled students rises above a certain number, regardless of denomination or other philosophies and views held by the founders. A fixed annual transfer from the central government is then being triggered by every student enrolled in a particular institution of secondary education. Furthermore, if a school's enrolment drops below a certain level, it can be shut down. As a consequence of this institutional setup, $70 \%$ of Dutch secondary schools are non-public schools.

Even though Walford (2000) criticizes increasing interventions of the central government when it comes to curricula and the size of teaching staff, it is still obvious that this education system complies with conceptions of a competitive school system harbored by proponents of school choice. Hence, it makes for an interesting subject of studying the implications of school choice.

\section{Empirical Strategy and Data Sources}

This section describes the general estimation approach used in testing the idea that schools which are exposed to higher levels of competition respond by providing superior school quality. It discusses various measures of school quality as well as competition. Furthermore, the possible endogeneity of the competition variable is addressed.

\footnotetext{
${ }^{5}$ For further information, go to: http://www.cito.nl/com_assess_ex/nat_final_ex/eind_fr.html

${ }^{6}$ In some subjects, no centralized testing occurs (e.g. physical education and arts). The analysis in this paper is limited to subjects where standardized central exams are given.
} 


\subsection{Estimation approach}

The data used in this paper comprises information on the graduating classes of 2002 and $2003 .^{7}$ The fact that the competition variable hardly varies from one year to another means that the focus of this paper is on cross-sectional analysis of the data. The impact of competition on educational achievement is estimated using the following baseline estimation equation:

$$
G_{i j}=\alpha C_{i j}+\mathbf{X}_{\mathbf{i}} \boldsymbol{\beta}+\mathbf{Z}_{\mathbf{j}} \boldsymbol{\delta}+\varepsilon_{i j},
$$

where $i$ denotes the individual $V W O$-school and $j$ education markets (in the context of this paper, this will typically be a municipality), $G_{i j}$ is the average centraal examen grade at school-level, $C_{i j}$ is the level of competition faced by school $i$ in market $j, \mathbf{X}_{\mathbf{i}}$ is a vector of control variables at the school level and $\mathbf{Z}_{\mathbf{j}}$ is a vector of control variables at the local geographic (municipality) level. To allow for the possible correlation of $\varepsilon_{i j}$ within geographic areas considered, the model allows for clustering of the standard errors at the municipality level.

\subsection{Measuring Competition and Achievement}

Two important questions have to be addressed before estimating the baseline equation:

(i) Which outcome measure is to be employed?

(ii) How should competition be measured?

Many measures come to mind when (i) is considered. This work uses school-level average grades in the central exit examinations. Even though quality of education involves so many more components than grades, they may well constitute one of the best available measures of educational output as they are considerably easier to grasp and measure than other aspects. These grades are determined by means of a central exam and central grading, administered by an independent institute (CITO). This practice renders them as close as one can get to an impartial measure of school quality, as long as one is willing to accept that the central exam tests the skills that should be conveyed by a Dutch secondary school. Since exams are mandatory, there is no worry about selection-bias, either, as would be the case with voluntary tests such as the American SAT (Scholastic Aptitude Test). Another variable that has often been used as an outcome are graduation rates. While this variable is available, in the Dutch setting it seems inappropriate, as half of the final grade and thus the graduation rate is determined via decentralized testing. In essence, this makes graduation rates (and standards) a choice variable for the individual school. $^{8}$

\footnotetext{
${ }^{7}$ Even though data on grades and some controls are available prior to 2001, due to a different system of standardization, these exam outcomes cannot be compared to post-2000 grades. For the class of 2001, some of the school level controls could not be obtained.

${ }^{8}$ On the setting of standards at the local level see Himmler and Schwager (2007).
} 
There are also numerous ways to capture the intensity of competition (ii). Probably most common is the use of a Herfindahl index of student enrollment, which measures the fragmentation of the student population within a given education market. The Herfindahl index that applies to a certain market $j$ is calculated as:

$$
H_{j}=\sum_{i=1}^{n} s_{i j}^{2},
$$

where $s_{i j}$ is the share of $V W O$-school $i$ 's students in the total number of $V W O$ students in market $j$.

An even more straightforward measure is the number of $V W O$-schools within an education market, as choice ultimately is a question of the number of alternatives that are on offer.

Even in the presence of school districts, the problem with the above measures is that it is a priori unclear what the geographical boundaries of an education market are. When Tiebout-sorting within a metropolitan area is present, it is insufficient to consider only those institutions within the same school district as a schools's competition. Hence, it makes more sense to count all schools within the metro area as competitors. The Dutch system of school choice without the need to relocate aggravates the problem, as parents can theoretically reside in Amsterdam and send their offspring to a school in a place as far away as Maastricht. As attending a farther away school entails travel cost, it is reasonable to assume that there are limits in terms of distance when it comes to the choice of school. ${ }^{9}$ Following Levin (2004), in this analysis it is assumed that the Dutch gemeenten constitute the boundaries to an education market and the Herfindahl index as well as the number of $V W O$-schools are calculated at the gemeente level. It seems reasonable to assume that people have some sort of attachment to the municipality where they reside and thus are likely to choose among schools located in the same municipality. Since it is, however, not necessary to attend a school within one's municipality of residence, the number of $V W O$ schools within a $15 \mathrm{~km}$ radius around the school in question is also used as a robustness check.

One measure that does not carry with it the need to define education markets is the distance in kilometers to the nearest $V W O$-school. Here, the argument is that competition increases in proximity as it becomes more feasible for students to transfer from one school to another. Any positive (or negative, for that matter) effects of competition should then be more pronounced when proximity is high.

In all of the above measures but the Herfindahl index, only catholic schools will be treated as competitors for the non-catholic schools. As Levin (2004) and Dronkers (2004) have stated, catholic schools outperform other forms of schooling, even after controlling for selection effects, making these schools all the more attractive. The reasoning then is that when parents choose a school, the real outside option to public/protestant schooling is a catholic school rather than another public or protestant school. It is also important

\footnotetext{
${ }_{9}^{9} \overline{\text { Denessen, Driessena and Sleegers (2005) }}$ find that among 17 reasons Dutch parents cited contributing to the choice of their school, proximity ranked 5th. School quality was found to be the most important reason for a particular choice.
} 
to notice that about $30 \%$ of all schools are catholic schools. This is a substantially higher share than in most other countries, making opting into the catholic school sector a possibility that is widely available.

Additionally, the effects of competition on the level of grade inflation are considered. It is often argued that an undesirable effect of competition may be that schools facing competitive pressure will try to attract students by inflating grades, that is, they will apply a lower grading standard. The measure of grade inflation is $\Delta G_{i j}=G_{i j}^{s}-G_{i j}^{c}$, where $G_{i j}^{c}$ denotes the average centraal examen grade and $G_{i j}^{s}$ the average schoolexamen grade in school $i$ in district $j$. The setting of average grades $G_{i j}^{c}$ is governed by the central standard defined by a committee of experts. The setting of school grades $G_{i j}^{s}$ on the other hand is governed by locally defined standards. Under coinciding central and school specific standards, one would expect $G_{i j}^{s}=G_{i j}^{c}$, because grading scales are identical in central and school exams. An upward deviation of $G_{i j}^{s}$ from $G_{i j}^{c}$ then constitutes a local standard that falls short of the central standard. If one is willing to accept that the centrally devised standard is the "true" standard, this may be interpreted as grade inflation.

The final outcome variable considered is per-student spending, which is expected to drop under competitive pressure as schools are forced to operate more efficiently. ${ }^{10}$

\subsection{Data Sources}

The data employed in this analysis stems from six different sources. Data on catholic population was provided by the Institute for Applied Research on Religion (KASKI) of the Radboud University Nijmegen. School-level data concerning students' present and (in an indirect measure) past performance along with personal traits such as social and cultural status is taken from the Kwaliteitskaart Voortgezet Onderwijs (Quality Cards for Secondary Education), issues 2002 - 2004. The Kwaliteitskaarten are published on a yearly basis by the Netherlands Inspectorate of Education and contain figures on examination results as well as efficiency measures for Dutch secondary schools. They are being made available to parents and children via the internet in order to facilitate choosing an appropriate secondary school. The school location information given in the Quality Cards are geocoded at the actual street address level and a matrix of distances between all schools is calculated.

The Kwaliteitskaarten dataset also provides school-level information on the number of students, administrative form of the school (private/denominational/public), the school branches that can be attended at the school, average class sizes, subject-level average grades attained in school and central exams, the recommended type of secondary school based on students' performance in primary education (i.e. students' entrance levels of performance), the percentage of ethnic minority students, the percentage of students receiving financial support from the government ('study cost allowance').

\footnotetext{
${ }^{10}$ If parents take per student spending as an indicator of school quality, there may also be a counteracting effect such that schools try to attract students by building a reputation of spending more money per student.
} 
The dependent variable $G_{i j}$ for the central exam is obtained directly from the dataset, whereas $\Delta G_{i j}$ for grade inflation is constructed from the performance data of the 2003 and 2004 Kwaliteitskaarten. As the original Kwaliteitskaarten file reports school-level average grades across subjects only for the central exam, the average school specific $\left(G_{i j}^{s}\right)$ and central $\left(G_{i j}^{c}\right)$ grades covering all subjects are calculated by weighting the average school and central grades in each subject with the number of students that have actually taken part in the exams in that particular subject. Apart from some 'placebo regressions', the empirical analysis will be restricted to the effect of catholic competition on the grades in non-catholic schools.

Controls are added for other possible determinants of academic performance. The percentage of cultural minority ( $C U M I)$ students is defined as the share of students in a given school branch who have a non-Dutch background. ${ }^{11}$ It is used along with the percentage of students receiving study cost allowance as a proxy for low social status. These proxies are used, as neither the Inspectorate nor the individual schools collect detailed data on the students' or parents' socioeconomic status.

At the end of basisschool each student is given a non-binding advice by her teachers as to which school branch is deemed appropriate in secondary education. Since grades from primary education are not available and the advice will obviously be largely based on grades in primary school, we add the advice as a control variable for the incoming students' skill level. Above advice denotes the share of students attending a more demanding branch than the one recommended, i.e. these students are in VWO, yet the given advice was for HAVO - which is the lower school branch adjacent to VWO - at the most. Half above advice denotes the percentage of students who did not get a clear VWO recommendation but rather were ranked in between HAVO and VWO. The percentage of students in ability-tracked classes in the first and second year of secondary education and the average class size from the Kwaliteitskaarten are also included. Ability-tracked in this context means that students attend classes with students from their chosen branch - which is VWO in the context of this paper - only, whereas non-tracked students attend classes together with students from other (lower) branches. After the second year of secondary education there are no mixed classes.

In addition to school level data, control variables which are available on the municipality and postcode level are used. Specifically, the Statusscore postcodegebieden is a postcode level index of quality of life in a given area. It thus proxies for the students' social background. They are supplied by The Social and Cultural Planning Office of the Netherlands (SCP), a Dutch government agency. The status scores are calculated in 4 year intervals, taking into account variables such as mean education, mean income, average rents etc. Postcode areas that have a low social status are denoted with values greater than zero, areas of higher status receive negative values. These scores are matched with the schools' 4-digit postcodes taken from the Kwaliteitskaarten. As they are updated every four years only, postcodes are assigned the same values in both years. Data on per capita income, the share of school aged children in the population, population density and the land area

\footnotetext{
${ }^{11}$ While 'cumi' is an official term in the Netherlands and there is a law that specifies the requirements to be considered part of a cultural minority, essentially these are students who themselves or whose parents were born in Eastern Europe or Third World countries.
} 
at the gemeente level comes from Nederland regionaal, published by the Dutch Office of Statistics $(C B S)$.

Since school-level financial endowment as well as characteristics of the teaching staff might influence average grades and standard setting as well as per-student spending, data from the series Onderwijs in Cijfers (OIC) is used in some of the estimations, too. Onderwijs in Cijfers is published annually by the Dutch Ministry of Education and is intended to provide school managers with information on the above mentioned matters. Variables included in the estimations are the share of short and long term debt in the total annual balance, the rate of student body growth or shrinkage, the rate of staff growth or shrinkage and the share of the staff that are part-timers with less than $80 \%$ of a full teaching position. However, data availability is a bit of a problem, as many variables are missing for a large number of schools. Another problem is that the data is not reported at the school level but rather for groups of schools.

Tables A-1 and A-2 in the appendix display descriptive statistics for the variables used in the estimation.

\section{Estimation Results}

As stated above, this work is concerned with the effect of catholic competition on noncatholic schools. ${ }^{12}$ In all of what follows, a further distinction is made between fully roman-catholic schools and schools that are only in part operated by the catholic church. These partly catholic schools include all kinds of cooperations of the catholic church with other organizations, such as catholic schools cooperating with private/public/protestant schools. If not stated otherwise the competition variable is the number of catholic schools in the municipality. ${ }^{13}$

Descriptive statistics for the dependent variables $G_{i j}, \Delta G_{i j}$ and per student spending are shown in tables 1 for the pooled classes of 2002 and 2003, split up by catholic schools and non-catholic schools. On average, grades awarded in central exams are slightly higher in catholic schools. Even though the difference is statistically significant, it does not seem very large, even for school-level averages. ${ }^{14}$

\footnotetext{
${ }^{12}$ non-catholic schools evidently include non-public schools which are not affiliated with the catholic church, such as protestant or private schools. These schools, neither operated by the catholic church nor public, make up about half of the non-catholic schools.

${ }^{13}$ There is one exception: The towns of Hoek van Holland and Hoogvliet are administered by the municipality of Rotterdam, yet they are located rather far away from the actual city. The town Hoek van Holland is $30 \mathrm{~km}$ away, while Hoogvliet is approximately $15 \mathrm{~km}$ from Rotterdam. Both towns do not directly border Rotterdam and other municipalities have to be traversed in order to reach Rotterdam. This can be seen in figure 6 in the appendix. For these reasons, Hoek van Holland and Hoogvliet are treated as education markets separate from Rotterdam.

${ }^{14}$ Keep in mind, though, that while individual grades range from 0 to 100 , most school-level averages range from 60 to 70 .
} 
Grade inflation on the other hand seems to be more prevalent in non-catholic schools, the difference in means is again statistically significant. Average spending per student is also higher in non-catholic schools. As schools can gain additional funds from the government when they have a large share of minority students enrolled, no statements on efficiency can be made from this data without controlling for student body composition.

The means of central exam grades and grade differences are significantly different across the groups for both definitions of catholic schools. In the end, however, it doesn't even matter whether or not these differences are significant but rather it matters whether students and their parents perceive catholic schools to be superior. From the data it also seems that the pure roman-catholic schools outperform even the partly catholic schools, yet parents may perceive the partly catholic schools mainly as 'catholic' and thus as an alternative to the non-catholic schools. The competition variable which includes these partly catholic schools may thus be the more appropriate one.

When it comes to the competition variables, table 2 shows that the average non-romancatholic school faces about one roman-catholic competitor, whereas the average noncatholic school faces about 1.4 competitors. The maximum amount of competitors is five. As can be expected from the fact that Dutch municipalities are rather small in land area, the number of competitors within $15 \mathrm{~km}$ is much higher than when the education market is defined at the municipality level. The larger competitor set of non-catholic schools also goes with a shorter distance to the nearest catholic school; the Herfindahl index ranges from 0.06 which is indicative of a pretty competitive market to 1 for those municipalities harboring one school only.

Table 1: Summary STATISTICS, DEPENDENT VARIABLES.

\begin{tabular}{lrrrrrrr}
\hline & \multicolumn{3}{c}{ (partly) catholic schools } & \multicolumn{2}{c}{ non (partly) catholic schools } \\
\cline { 2 - 6 } \multicolumn{1}{c}{ Variable } & $\mathbf{N}$ & Mean & SD & N & Mean & SD & diff $\neq 0$ \\
\hline Central grade & 369 & 64.40 & 2.59 & 639 & 63.91 & 3.08 & ${ }^{* *}$ \\
Grade inflation & 369 & 4.39 & 2.17 & 639 & 5.08 & 2.81 & ${ }^{* * *}$ \\
Per student spending & 176 & 5880 & 1257 & 308 & 6032 & 1175 & $n o$ \\
\hline
\end{tabular}

\begin{tabular}{lrrrrrrr}
\hline & \multicolumn{9}{c}{ Roman-catholic schools } & \multicolumn{2}{c}{ non Roman-catholic schools } \\
\cline { 2 - 6 } \multicolumn{1}{c}{ Variable } & N & Mean & SD & N & Mean & SD & diff $\neq 0$ \\
\hline Central grade & 275 & 64.63 & 2.41 & 733 & 63.89 & 3.07 & $* * *$ \\
Grade inflation & 275 & 4.16 & 2.04 & 733 & 5.08 & 2.76 & $* * *$ \\
Per student spending & 129 & 5827 & 1305 & 355 & 6032 & 1166 & $*$ \\
\hline
\end{tabular}

The upper part considers all schools that are in part catholic as competition, whereas the bottom part considers only fully Roman-Catholic schools as competition.

${ }^{*} p<0.10,{ }^{* *} p<0.05,{ }^{* * *} p<0.01$

Estimation results when the central grade is used as the outcome variable are presented in table 3 for non-catholic schools ${ }^{15}$ and in table 4 for non-roman-catholic schools. ${ }^{16}$ Spec-

\footnotetext{
${ }^{15}$ Non-catholic schools are not even partly operated by the catholic church. The competition variable thus includes schools that are only in part operated by the catholic church.

${ }^{16}$ Non-roman-catholic schools may be partly operated by the catholic church, yet they are not fully romancatholic. The competition variable thus includes only those schools that are fully operated by the catholic church.
} 
Table 2: Summary Statistics, COMPetition VARiables.

\begin{tabular}{lrrrrr}
\hline & \multicolumn{5}{c}{ non (partly) catholic schools } \\
\cline { 2 - 6 } \multicolumn{1}{c}{ Variable } & $\mathbf{N}$ & Mean & SD & Min & Max \\
\hline No. cath. schools gemeente & 639 & 1.41 & 1.67 & 0 & 5 \\
No. cath. schools 15km radius & 639 & 4.96 & 4.11 & 0 & 15 \\
km to (partly) cath. school & 639 & 6.16 & 7.29 & 0.08 & 42.55 \\
Herfindahl gemeente & 631 & 0.40 & 0.31 & 0.06 & 1 \\
\hline & \multicolumn{7}{c}{ non Roman-catholic schools } \\
\hline \multicolumn{1}{c}{ Variable } & Mean & SD & Min & Max \\
\hline No. cath. schools gemeente & 733 & 0.97 & 1.33 & 0 & 5 \\
No. cath. schools 15km radius & 733 & 3.44 & 3.03 & 0 & 12 \\
km to Roman-cath. school & 733 & 12.23 & 17.41 & 0.15 & 86.66 \\
Herfindahl gemeente & 725 & 0.42 & 0.32 & 0.06 & 1 \\
\hline
\end{tabular}

The upper part considers all schools that are not even in part catholic schools, whereas the bottom part considers those schools that are not Roman-Catholic schools.

ification (1) includes the number of competitors and a year dummy only. Whenever municipality characteristics are added in column (2), the coefficient on competition actually becomes positive and in the case of non-catholic schools significant. Including school level control variables in column (3) further increases the effect of competition. It can be seen that the school level variables now pick up the effects from the municipality level controls, all of which now turn insignificant. The control variables mostly point in the theoretically expected direction. A high share of minority students and students whose advice after basisschool deemed $V W O$ too demanding lead to lower average grades. The same goes for a high percentage of untracked students. Somewhat surprising is the highly significant positive coefficient of class size. This could be due to the fact that Dutch schools receive extra funding for low ability students. These funds are often used to lower class size. In the end this means that smaller classes are a proxy of sorts for a high number of underachieving students. The non-religious school dummy has a negative coefficient, indicating that among the non-catholic schools, those schools not affiliated with any religion perform even worse. ${ }^{17}$ Including school finance measures in column (4) does not alter the results from column (3) much. The financial variables do not add much in terms of explanatory value, as only short term debt is even marginally significant. This is not too surprising, as these variables are reported at an aggregated level of groups of schools. On the downside, many observations are lost due to the limited availability of the financial variables. To put the coefficients into perspective, a one standard deviation change in competition increases central exam grades by 0.15 (non-catholic schools) and 0.1 (non-roman-catholic schools) standard deviations, respectively. This is not a huge effect, but according to Belfield and Levin (2002) in the range of what other studies find. Overall, it seems that competition has a small but significant positive impact on central exam grades.

\footnotetext{
${ }^{17}$ Alternatively, dummies for the specific denominations can be included. This leaves the results unchanged, the only two significant dummies are those for the non-catholic religious schools. The non-religious school dummy thus captures the same effect. Similarly, including dummies for the Dutch dioceses (bisdommen) does not significantly reduce the estimated effect of competition.
} 
In order to retain as many observations as possible, from here on only specification (3) is used, as the additional controls do not add much in terms of explanatory value yet they significantly reduce the sample size. In addition, we were unable to obtain information from the Dutch authorities with regards to why so many observations are missing. It is thus not clear on what criteria the smaller sample would be selected, i.e. whether schools report their financial data voluntarily. In that case, a selection model would have to be estimated to obtain unbiased results.

\subsection{Endogeneity of Competition}

Another issue that has to be dealt with is the possible endogeneity of competition to local school quality. That is, in an area where public school quality is low, demand for alternative forms of schooling may be especially high, causing a downward bias in the competition coefficients estimated by OLS. To overcome this problem, 2SLS estimation is employed, where the estimation equations are

$$
C_{i j}=\gamma_{0}+\mathbf{I}_{\mathbf{j}} \gamma_{1}+\mathbf{X}_{\mathbf{i}} \gamma_{2}+\mathbf{Z}_{\mathbf{j}} \gamma_{3}+u_{i j}
$$

and

$$
G_{i j}=\beta_{0}+\beta_{1} C_{i j}+\mathbf{X}_{\mathbf{i}} \boldsymbol{\beta}_{2}+\mathbf{Z}_{\mathbf{j}} \boldsymbol{\beta}_{3}+\varepsilon_{i j} .
$$

The first stage is given by (3) and the second stage by (4), where the definitions are as in (1) and $I_{j}$ is the set of instruments.

The instruments proposed are the number of catholics living in the education market and its square. As catholics tend to found and attend catholic schools, their number is obviously closely related to the number of catholic schools in the education market. Exogeneity can be assumed because there is no reason to believe that catholics fare better on standardized tests. Moreover, geographical areas where catholics dominate are largely historically predetermined.

The first stage results (table 5) indicate that both instruments are highly significant and that there is no problem with weak instruments. The second stage coefficients (table 6) are scaled down a bit compared with the OLS results and as is always the case with 2SLS the standard errors increase significantly, rendering the effect of competition insignificant for non-roman-catholic schools. Hausman tests of statistical differences in the OLS and 2SLS estimates, however, fail to reject exogeneity of the competition variable in both cases. When it comes to instrument exogeneity, standard overidentification tests fail to reject the exogeneity of the instruments at any reasonable level.

It should be noted however, that the overidentification tests do not carry much weight here, as both instruments are derived from the same reasoning. Thus, in an alternative specification shown in tables A-3 and A-4 in the appendix, the total length of the road network within a municipality is used as an additional instrument. This instrument is closely related to population size, which is used as an instrument for competition by Geller, Sjoquist and Walker (2006) as well as Hsieh and Urquiola (2006), yet it also takes 


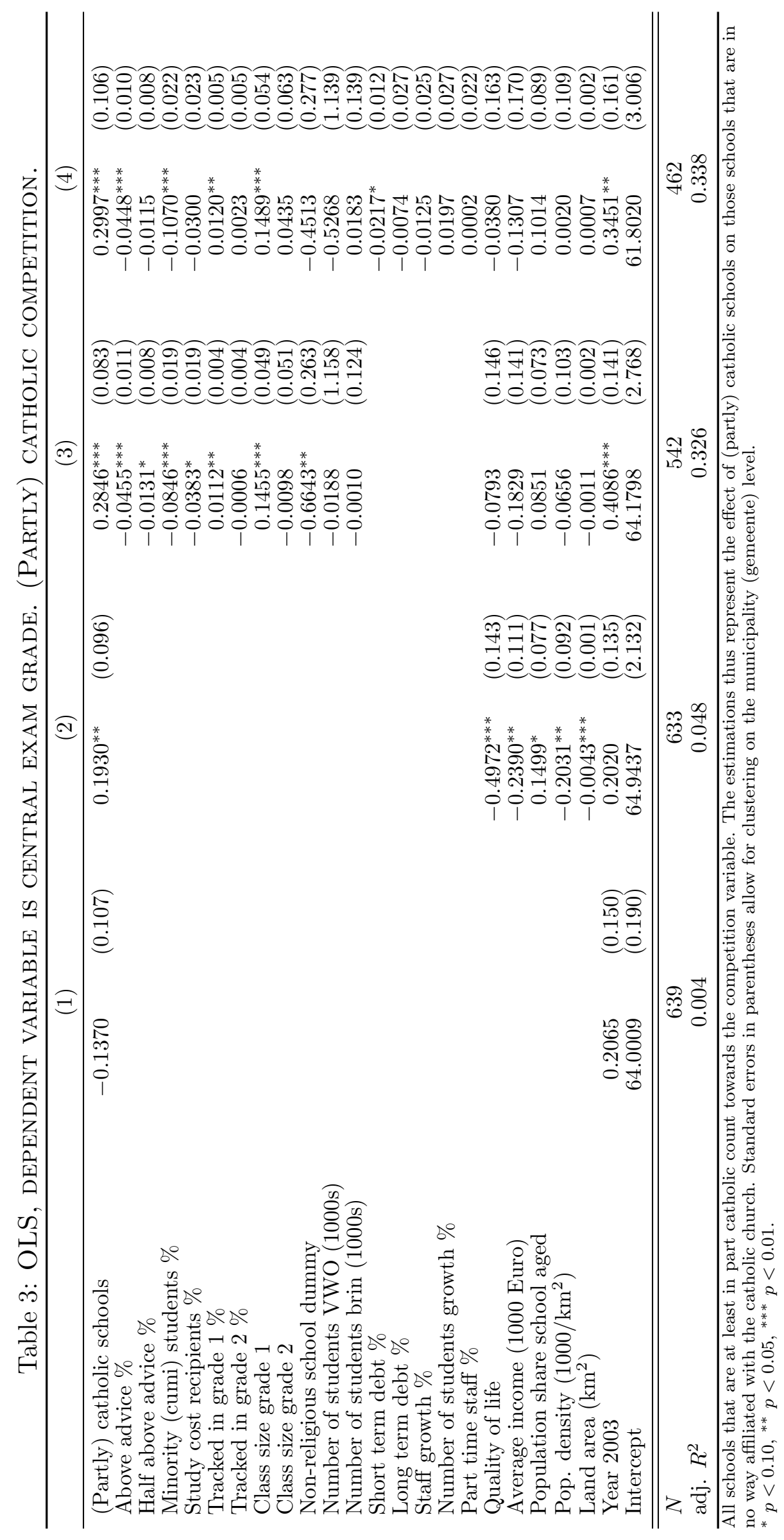




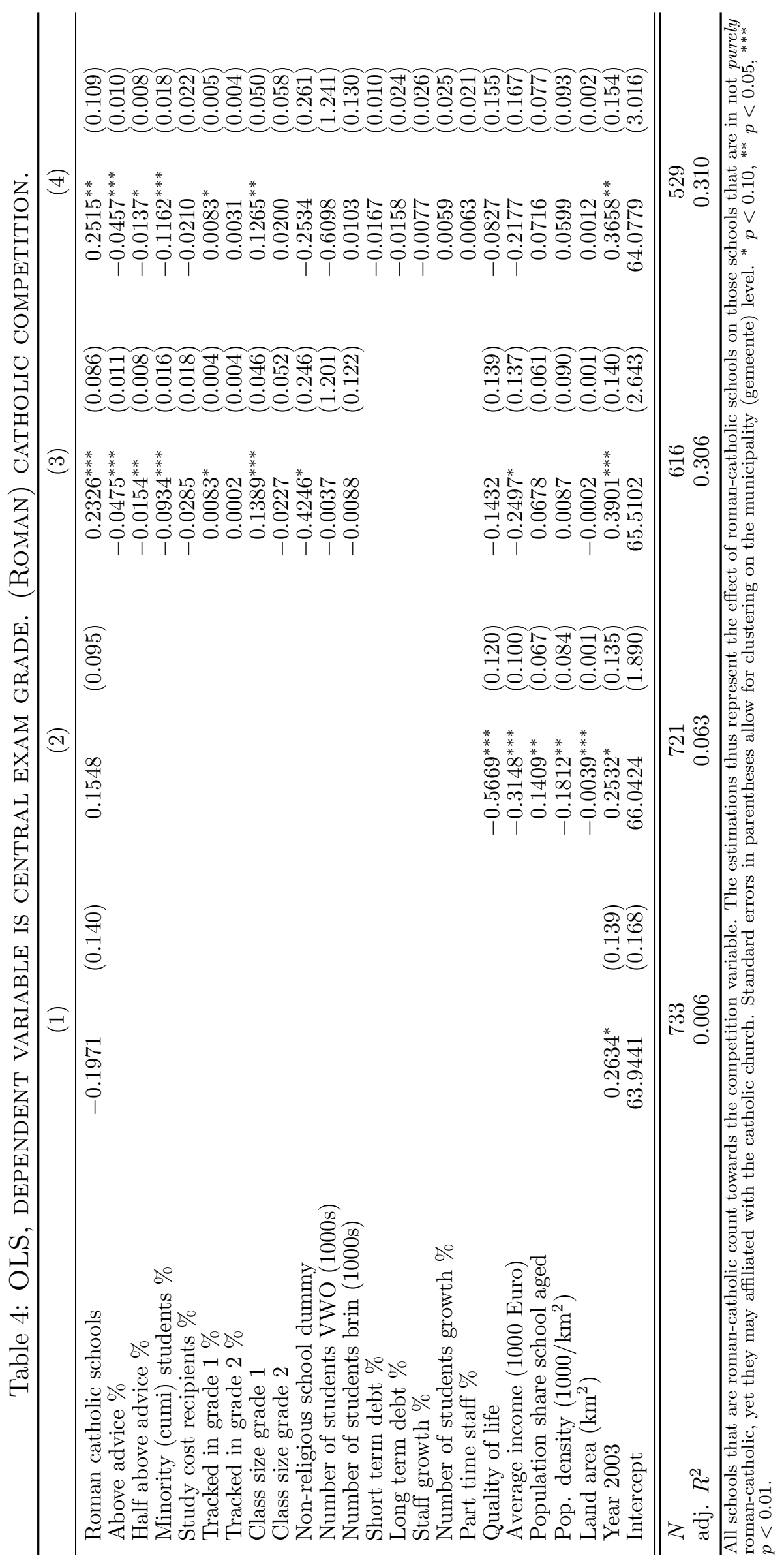


into account the accessibility of schools. ${ }^{18}$ Any urban/rural differences in achievement are tried to capture by controlling for population density and land area at the market level. Population density should also not react to school quality, as it is not necessary to physically move to the vicinity of the school of choice. The results from these alternative 2SLS estimations are virtually identical and the overidentification statistic is even smaller.

In the end, the 2SLS results indicate that we can have some confidence in the validity of the baseline OLS results.

Table 5: FiRst STAGE STATISTICS.

(1)

(2)

\begin{tabular}{|c|c|c|c|c|}
\hline & \multicolumn{2}{|c|}{$\begin{array}{l}\text { (Partly) catholic } \\
\text { (P) }\end{array}$} & \multicolumn{2}{|c|}{ Roman-catholic } \\
\hline Catholics in municip. (1000s) & $0.1071^{* * *}$ & $(0.0112)$ & $0.0643^{* * *}$ & $(0.0166)$ \\
\hline Cath in municip. squared & $-0.0007^{* * *}$ & $(0.0001)$ & $-0.0003^{*}$ & $(0.0002)$ \\
\hline F-test excluded instr. & \multirow{2}{*}{\multicolumn{2}{|c|}{$\begin{array}{c}\mathrm{F}(2,140)=58.36 \\
\mathrm{p}=0.000 \\
0.61\end{array}$}} & \multirow{2}{*}{\multicolumn{2}{|c|}{$\begin{array}{c}\mathrm{F}(2,153)=15.63 \\
\mathrm{p}=0.000 \\
0.41\end{array}$}} \\
\hline partial $R^{2}$ excluded instr. & & & & \\
\hline $\begin{array}{l}R^{2} \\
N\end{array}$ & \multicolumn{2}{|c|}{$\begin{array}{l}0.83 \\
542\end{array}$} & \multicolumn{2}{|c|}{$\begin{array}{l}0.66 \\
616\end{array}$} \\
\hline
\end{tabular}

\subsection{Robustness checks}

Table 7 displays results for some alternative specifications. In all of these, the dependent variable is the central exam grade. The top part (a) of the table shows that the effect of catholic competition on public schools is somewhat larger than for all non-catholic schools. This is intuitively consistent with the finding that non-religious schools are the worst schools among the non-catholic schools.

Because there may be urban/rural differences in the effects of competition and because catholic competition might not have as much of an effect in predominantly catholic dioceses, part (b) of the table shows how sensitive the results are to dropping these schools from the sample. ${ }^{19}$ While dropping the grote 4 (big 4) cities Amsterdam, Utrecht, Rotterdam and Den Haag slightly reduces the competition effects, the impact of catholic alternatives seems to be especially large in those dioceses that are not predominantly catholic. The effect of catholic competition seems to be largest in non-catholic areas outside the grote 4.

An important question is whether the effect of competition is truly an effect that can

${ }^{18}$ Gibbons and Olmo (2006) find that academic achievement is higher in urban areas of the UK. This could cast doubt on the assumption of exogeneity. However, they expressly attribute this effect to higher levels of competition.

${ }^{19}$ The dioceses of Roermond, Breda and Den Bosch are classified as predominantly catholic dioceses because the share of catholics in the population is above $40 \%$ in all three. 
Table 6: 2SLS, DEPENDENT VARIABLE IS CENTRAL EXAM GRADE.

$(1)$

(Partly) catholic

\begin{tabular}{|c|c|c|c|c|}
\hline (Partly) catholic schools & $0.2434^{*}$ & $(0.127)$ & & \\
\hline Roman catholic schools & & & 0.1700 & $(0.155)$ \\
\hline Above advice $\%$ & $-0.0456^{* *}$ & $(0.011)$ & $-0.0473^{* * *}$ & $(0.010)$ \\
\hline Half above advice $\%$ & $-0.0136^{*}$ & $(0.008)$ & $-0.0157^{* *}$ & $(0.008)$ \\
\hline Minority (cumi) students \% & $-0.0831^{* *}$ & $(0.020)$ & $-0.0915^{* * *}$ & $(0.017)$ \\
\hline Study cost recipients \% & $-0.0384^{* *}$ & $(0.019)$ & -0.0289 & $(0.018)$ \\
\hline Tracked in grade $1 \%$ & $0.0111^{* *}$ & $(0.004)$ & $0.0083^{*}$ & $(0.004)$ \\
\hline Tracked in grade $2 \%$ & -0.0007 & $(0.004)$ & 0.0002 & $(0.004)$ \\
\hline Class size grade 1 & $0.1466^{* *}$ & $(0.048)$ & $0.1413^{* * *}$ & $(0.045)$ \\
\hline Class size grade 2 & -0.0101 & $(0.050)$ & -0.0233 & $(0.052)$ \\
\hline Non-religious school dummy & $-0.6707^{* *}$ & $(0.264)$ & $-0.4278^{*}$ & $(0.244)$ \\
\hline Number of students VWO (1000s) & 0.0414 & $(1.182)$ & 0.0869 & $(1.247)$ \\
\hline Number of students brin (1000s) & -0.0055 & $(0.121)$ & -0.0147 & $(0.119)$ \\
\hline Quality of life & -0.0757 & $(0.146)$ & -0.1381 & $(0.140)$ \\
\hline Average income (1000 Euro) & -0.1818 & $(0.138)$ & $-0.2497^{*}$ & $(0.135)$ \\
\hline Population share school aged & 0.0748 & $(0.075)$ & 0.0557 & $(0.063)$ \\
\hline Pop. density $\left(1000 / \mathrm{km}^{2}\right)$ & -0.0507 & $(0.097)$ & 0.0221 & $(0.087)$ \\
\hline Land area $\left(\mathrm{km}^{2}\right)$ & -0.0008 & $(0.001)$ & 0.0000 & $(0.001)$ \\
\hline Year 2003 & $0.4060^{* *}$ & $(0.137)$ & $0.3859^{* * *}$ & $(0.137)$ \\
\hline Intercept & 64.3534 & $(2.741)$ & 65.6897 & $(2.627)$ \\
\hline $\begin{array}{l} \\
\text { adj. } R^{2}\end{array}$ & \multicolumn{2}{|c|}{$\begin{array}{c}542 \\
0.325\end{array}$} & \multicolumn{2}{|c|}{$\begin{array}{c}616 \\
0.306\end{array}$} \\
\hline test of overid. restr. $\chi^{2}(1)$ & 0.010 & $(p=0.920)$ & 0.145 & $(p=0.703)$ \\
\hline
\end{tabular}

only be found when catholic schools are treated as the competitors. The bottom part (c) of table 7 shows that the number of other schools than the catholic ones does not have an impact on exam grades and that catholic competition does not improve the outcome for other catholic schools. These estimates are in line with the assumption of this paper that competition in the Netherlands is mainly inter-denominational and affects the noncatholic schools

Other proxies for competition are employed in table 8. The number of schools within a $15 \mathrm{~km}$ radius is significant at the ten percent level. If it is in fact true that households mostly choose schools that are located within their own gemeente, then the $15 \mathrm{~km}$ radius is an inappropriate specification as it will almost inevitably contain schools in other municipalities. The same argument is true for distance to the nearest catholic school (not significant), as this will sometimes be the distance to a school outside the municipality. In addition, a drawback of the data used is that all distances are calculated 'as the crow flies', thus neglecting geographical obstacles such as rivers or bad connecting roads between places. The Herfindahl measure of competition does not solely depend on catholic school competition. Higher concentration is associated with lower average grades, yet the coefficient is significant only in one of the 2SLS estimations. Even though the Herfindahl index comprises the shares of all schools in a market, it is still heavily influenced by the number of catholic schools in the market. Thus, the significant coefficient does not stand 
Table 7: Robustness CHeCKS, DePendent VARIABle EXAM GRAde.

(1)

(2)

(Partly) catholic

Roman-catholic

(a) catholic competition, effect on public schools

Number of catholic schools in muni.

$0.3723^{* * *}$

$(0.129)$

Number of rom.-cath. schools in muni.

$0.3353^{* *}$

$(0.137)$

(b) catholic competition (\# cat schools), sub-samples

Catholic, w/out big 4 cities

Rom.-cath., w/out big 4 cities

Catholic, w/out cath. dioceses

Rom.-cath., w/out cath. dioceses

Catholic, w/out big 4 and cath. dioc.

Rom.-cath., w/out big 4 and cath. dioc.

$0.2494^{* *}$
$0.3409^{* * *}$
$0.3711^{* * *}$

$0.3711^{* * *}$

$0.3027^{* * *}$

$0.3595^{* *}$

\section{(c) other forms of competition, placebo regressions}

All competitors on all schools

All competitors on non-cat. schools

All competitors on non-rom.-cat. schools

Cat. competitors on cat. schools

R.-cat. competitors on rom.-cat. schools

Non-cat. competitors on all schools

Non-rom.-cat. comp. on all schools

Non-cat. competitors on non-cath schools

Non-rom.-cat. comp. on non-rom.-cath. sch.

Non-cat. competitors on cath. schools

Non-rom.-cat. comp. on rom.-cath. schools

$\begin{array}{rr}0.0293 & (0.036) \\ 0.0461 & (0.047) \\ 0.0380 & (0.043) \\ -0.0034 & (0.118) \\ 0.0119 & (0.146) \\ -0.0049 & (0.046) \\ 0.0080 & (0.041) \\ 0.0174 & (0.059) \\ 0.0192 & (0.050) \\ -0.0835 & (0.077) \\ -0.0245 & (0.095)\end{array}$

Part (a) shows the effect of 'number of catholic/roman-catholic schools in municipality' on central exam grades in public schools. Part (b) shows the coefficients of the variable 'number of catholic/ roman-catholic schools in municipality'. The bottom part (c) shows coefficients for other forms of competition that are not believed to have an effect on academic achievment. Where applicable, all schools that are at least in part catholic schools count towards the competition variable in column (1), whereas only roman-catholic schools are considered in column (2). Only coefficients of the competition variable are displayed. Control variables are as in column (3) of the baseline OLS tables 3 and 4 . Standard errors in parentheses allow for clustering on the municipality (gemeente) level.

${ }^{*} p<0.10,{ }^{* *} p<0.05,{ }^{* * *} p<0.01$.

against the hypothesis that catholic schools are the real competition. Quite the contrary, the effect should be reduced in comparison to a competition measure that considers only catholic schools. Taken together, the rather weak results for the alternative competition measures provide some support for treating the municipalities as separate education markets.

\subsection{Alternative outcome variables}

Two alternative outcomes of competition are considered in this section. When it comes to per-student spending, there is clearly no effect to be found. ${ }^{20}$ More interesting results are

${ }^{20}$ The only significant effect is found for the distance measure. The farther the nearest catholic school is away, the more money non-catholic schools spend per student. Since the distance measure did not have an effect on exam grades, an interpretation of this result is hard to come up with. In addition, the per 


\section{OLS estimates}

Cath. schools w/in $15 \mathrm{~km}$ $0.075^{* *}$ 0.004

$\mathrm{km}$ to nearest catholic school

$0.004 \quad(0.021)$

Roman-cath. schools w/in $15 \mathrm{~km}$

$-0.685$

$(0.572)$

$\mathrm{km}$ to nearest rom.-cath. school $-0.685$

$-0.385$

\section{SLS estimates}

Cath. schools w/in $15 \mathrm{~km}$

$\begin{array}{ll}0.137^{*} & (0.075) \\ -0.057 & (0.038)\end{array}$

$\mathrm{km}$ to nearest catholic school

$-0.057$

$(0.038)$

to schools w/in $15 \mathrm{~km}$

$$
-1.719^{*}
$$

0.079
-0.011
-0.774

$(0.082)$

$(0.015)$

(1.068)

OLS estimates in upper half, second stage 2SLS estimates in bottom part of table. Instruments are the number of catholics in the municipality and its square. All schools that are at least in part catholic schools count towards the competition variable in column (1), whereas only roman-catholic schools are considered in column (2). Control variables are as in column (3) of the baseline OLS tables 3 and 4. Standard errors in parentheses allow for clustering on the municipality (gemeente) level.

${ }^{*} p<0.10,{ }^{* *} p<0.05,{ }^{* * *} p<0.01$.

obtained for the effect of competition on grade inflation. As stated above, theory suggests that under competitive pressure, schools will tend to award higher schoolexamen-grades in order to attract students. Somewhat puzzling is the fact that OLS results show that higher levels of competition actually induce lower levels of grade inflation. ${ }^{21}$ The magnitude of the effect is similar to the effect on central grades: a one standard deviation shift in competition lowers grade inflation by 0.1 standard deviations. In light of the finding that competition increases the central exam grades, this means that obviously schools do not react to competition by inflating local school grades by the same amount.

This section so far has provided some tentative evidence that competition may not be so detrimental after all, not even when it comes to grade inflation.

\section{Distributional Analysis - QR and IVQR}

Whenever competition in the education sector is discussed, a major concern is that the consequences of choice may be very different at different points of the achievement distribution. Specifically, it is often argued, that the best schools will be able to lure the most able students away from the badly performing schools. When this is the case, positive effects of competition on the mean school may still be observed, that is, the average effect of competition may be beneficial. At the same time, it may be the case that the effects of

student spending data is available for only roughly half of the schools.

${ }^{21}$ 2SLS results are not reported, since Hausman tests again fail to reject exogeneity of the competition variable. 


\section{catholic competition, effect on grade inflation}

Number of catholic schools in muni. Number of rom.-cath. schools in muni. $N$
$-0.1695^{*}$

$(0.0899)$

$542-0.1601^{*}$

\section{catholic competition, effect on per student spending}

Number of catholic schools in muni. $\quad-1.8138$ Number of rom.-cath. schools in muni. $N$

$$
-1.8138
$$

estimates of the effect of 'number of catholic/roman-catholic schools in municipality' on grade inflation and per student spending. Control variables are as in column (3) of the baseline OLS tables 3 and 4 . Standard errors in parentheses allow for clustering by municipality.

${ }^{*} p<0.10,{ }^{* *} p<0.05,{ }^{* * *} p<0.01$.

competition are actually negative for the underachieving schools because they lose their most able students to the 'elite' schools at the upper tail of the achievement distribution for whom the effects of competition would then be positive. Thus, the results presented in the previous section are misleading, whenever the effect varies across the distribution. A tool that is very useful in this context is quantile regression (QR), as proposed by Koenker and Bassett (1978). In general notation, it allows the calculation of the $\tau$-th quantile of a dependent variable $Y$ given the independent variables $X$ by solving:

$$
\boldsymbol{\beta}(\tau)=\arg \min _{\boldsymbol{\beta}} E\left[\rho_{\tau}(Y-\mathbf{X} \boldsymbol{\beta})\right]
$$

where $\rho_{\tau}$ is the 'check function' or 'loss function' given by:

$$
\rho_{\tau}(\varepsilon)=[\tau-1(\varepsilon<0)] \varepsilon
$$

and $\varepsilon=(Y-\mathbf{X} \boldsymbol{\beta})$. The check function thus generates asymmetrically weighted absolute residuals. The $\boldsymbol{\beta}$ that minimizes equation (5) contains the parameters of interest for quantile $\tau$.

A quantile regression in the context of this paper can be written in the form of a random coefficients model. The effect of competition on academic achievement in the presence of heterogenous effects across the distribution of the outcome variable can then be represented by the following estimation equation: 


$$
G_{i j}=\alpha(U) C_{i j}+\mathbf{X}_{\mathbf{i}} \boldsymbol{\beta}(\boldsymbol{U})+\mathbf{Z}_{\mathbf{j}} \boldsymbol{\delta}(\boldsymbol{U})+\varepsilon_{i j}(U)
$$

where - as defined earlier in the paper $-G_{i j}$ are academic outcomes, $C_{i j}$ is the measure of competition and $\mathbf{X}_{\mathbf{i}}$ as well as $\mathbf{Z}_{\mathbf{j}}$ are vectors of control variables. ${ }^{22}$ In the spirit of Doksum (1974), the rank term $U$ can be interpreted as unobserved, innate ability or proneness (in this context, e.g. proneness to learn). Unobserved ability is normalized to be uniformly distributed and thus represent the rank of the individuals when it comes to ability: $U \mid C, \mathbf{X}_{\mathbf{i}}, \mathbf{Z}_{\mathbf{j}} \sim$ Uniform $(0,1)$. Individuals with the same observable characteristics will exhibit heterogenous outcomes whenever their rank in U differs. The use of QR can thus be interpreted as accounting for unobserved heterogeneity.

While QR has become increasingly popular in the recent past (perhaps due to its now wide availability in commonly used statistics packages), conventional QR suffers from the same problems as OLS whenever endogeneity is present. That is, equation (7) gives unbiased results only if competition is not determined together with $U$. As has been laid out earlier, it is not unlikely that $C_{i j}$ may be statistically dependent on $U$. This means that even though in the previous sections of this paper, 2SLS estimates did not point to any endogeneity issues at the mean, things may be different at other quantiles. As endogeneity problems can be countered through the use of instrumental variables in regular OLS situations, intuitively the question of whether IV methods can be applied to $\mathrm{QR}$ comes to mind. Indeed, a method of coping with endogeneity in the context of QR has been suggested and further developed by Chernozhukov and Hansen (2005, 2006, 2007 and 2008) and has been dubbed instrumental variable quantile regression or inverse quantile regression (IVQR). ${ }^{23}$

Again using the random coefficients model from equation (7), the assumptions underlying the IVQR model are:

(a1) $\alpha(U) C_{i j}+\mathbf{X}_{\mathbf{i}} \boldsymbol{\beta}(\boldsymbol{U})+\mathbf{Z}_{\mathbf{j}} \boldsymbol{\delta}(\boldsymbol{U})$ is strictly increasing in $U$.

(a2) $U \mid \mathbf{X}_{\mathbf{i}}, \mathbf{Z}_{\mathbf{j}}, \mathbf{I}_{\mathbf{i j}} \sim$ Uniform $(0,1)$. $U$ is independent of $\mathbf{X}_{\mathbf{i}}, \mathbf{Z}_{\mathbf{j}}$ and the instruments $\mathbf{I}_{\mathbf{i j}}$ which are excluded from the structural equation (7) (where $\mathbf{I}$ consists of at least as many instruments as there are endogenous variables, $\operatorname{dim}(\mathbf{I}) \geq \operatorname{dim}(C))$. In what follows, it is possible to plug in the instruments themselves into the regressions. Alternatively, one can run a 'first stage', where similar to 2SLS, the endogenous variable is linearly projected onto the exogenous variables plus the excluded instruments. The predicted values of the endogenous variable then make up $\mathbf{I}_{\mathbf{i j}}$. The latter approach is chosen for the estimations in this paper.

(a3) Rank invariance or rank similarity: Under each realization of the endogenous variable $C_{i j}$, an observation's rank would stay the same or change only in terms of

${ }^{22}$ The corresponding fixed coefficients model with additive disturbances can be written as: $G_{i j}=\alpha C_{i j}+$ $\mathbf{X}_{\mathbf{i}} \boldsymbol{\beta}+\mathbf{Z}_{\mathbf{j}} \boldsymbol{\delta}+\varepsilon_{i j}(U)$.

${ }^{23}$ IVQR has not yet been implemented in any statistics packages, yet the MATLAB code is kindly provided by Chris Hansen on his website. 
random slippages.

From the structural equation (7) and the monotonicity assumption (a1) it can be seen that $G_{i j} \leq \alpha(\tau) C_{i j}+\mathbf{X}_{\mathbf{i}} \boldsymbol{\beta}(\boldsymbol{\tau})+\mathbf{Z}_{\mathbf{j}} \boldsymbol{\delta}(\boldsymbol{\tau})$ is equivalent to $U \leq \tau$ where $\tau$ denotes the quantile of interest. Considering (a1) and (a2), it then follows that

$$
P\left[G_{i j} \leq Q_{G}\left(\tau \mid C_{i j}, \mathbf{X}_{\mathbf{i}}, \mathbf{Z}_{\mathbf{j}}\right) \mid \mathbf{X}_{\mathbf{i}}, \mathbf{Z}_{\mathbf{j}}, \mathbf{I}_{\mathbf{i j}}\right]=\tau,{ }^{24}
$$

which is equivalent to

$$
P\left[G_{i j} \leq \alpha(\tau) C_{i j}+\mathbf{X}_{\mathbf{i}} \boldsymbol{\beta}(\boldsymbol{\tau})+\mathbf{Z}_{\mathbf{j}} \boldsymbol{\delta}(\boldsymbol{\tau}) \mid \mathbf{X}_{\mathbf{i}}, \mathbf{Z}_{\mathbf{j}}, \mathbf{I}_{\mathbf{i j}}\right]=\tau .
$$

This moment condition is what Chernozhukov and Hansen $(2005,2006)$ call the main implication of the model. Equation (9) essentially states that the $\tau$-th quantile of the random variable $G_{i j}-\alpha(\tau) C_{i j}-\mathbf{X}_{\mathbf{i}} \boldsymbol{\beta}(\boldsymbol{\tau})-\mathbf{Z}_{\mathbf{j}} \boldsymbol{\delta}(\boldsymbol{\tau})$ given $\mathbf{X}_{\mathbf{i}}, \mathbf{Z}_{\mathbf{j}}, \mathbf{I}_{\mathbf{i j}}$ is equal to zero.

The coefficients $\boldsymbol{\beta}^{*}, \boldsymbol{\delta}^{*}$ and most importantly $\boldsymbol{\gamma}$ should then equal zero in the following quantile regression:

$$
G_{i j}-\alpha(\tau) C_{i j}-\mathbf{X}_{\mathbf{i}} \boldsymbol{\beta}(\boldsymbol{\tau})-\mathbf{Z}_{\mathbf{j}} \boldsymbol{\delta}(\boldsymbol{\tau})=\mathbf{X}_{\mathbf{i}} \boldsymbol{\beta}^{*}(\tau)+\mathbf{Z}_{\mathbf{j}} \boldsymbol{\delta}^{*}(\tau)+\mathbf{I}_{\mathbf{i j}} \gamma(\tau),
$$

Since $\alpha(\tau)$ in equation (10) is unknown, an $\widehat{\alpha}(\tau)$ must be chosen so that it minimizes the distance of $\gamma$ from zero. For a finite sample size $n$ this can be evaluated using a Wald statistic $W_{n}(\alpha)$ and the coefficient $\widehat{\alpha}(\tau)$ can be chosen accordingly:

$$
\widehat{\alpha}(\tau)=\arg \inf _{\alpha \in \mathcal{A}} W_{n}(\alpha)
$$

where

$$
(\widehat{\boldsymbol{\beta}}(\alpha, \tau), \widehat{\boldsymbol{\delta}}(\alpha, \tau), \widehat{\boldsymbol{\gamma}}(\alpha, \tau))=\arg \inf _{(\boldsymbol{\beta}, \boldsymbol{\delta}, \boldsymbol{\gamma})} Q_{G, n}(\tau, \alpha, \boldsymbol{\beta}, \boldsymbol{\delta}, \boldsymbol{\gamma})
$$

and $\mathcal{A}$ is a grid of potential values for $\alpha, W_{n}(\alpha)=n(\widehat{\gamma}(\alpha, \tau))^{\prime} \widehat{M}(\alpha)(\widehat{\gamma}(\alpha, \tau))$ and $M(\alpha)$ is

\footnotetext{
${ }^{24} \overline{\text { The conditional quantiles } Q_{G}\left(\tau \mid C_{i j}, \mathbf{X}_{\mathbf{i}}, \mathbf{Z}_{\mathbf{j}}\right)}=\alpha(\tau) C_{i j}+\mathbf{X}_{\mathbf{i}} \boldsymbol{\beta}(\boldsymbol{\tau})+\mathbf{Z}_{\mathbf{j}} \boldsymbol{\delta}(\boldsymbol{\tau})$ of the structural QR equation suffer from endogeneity bias. Thus, Chernozhukov and Hansen (2008) define the structural quantile function (SQF) as $S_{G}\left(\tau \mid c_{i j}, \mathbf{x}_{\mathbf{i}}, \mathbf{z}_{\mathbf{j}}\right)=\alpha(\tau) c_{i j}+\mathbf{x}_{\mathbf{i}} \boldsymbol{\beta}(\boldsymbol{\tau})+\mathbf{z}_{\mathbf{j}} \boldsymbol{\delta}(\boldsymbol{\tau})$, where the lowercase variables denote realizations of the random variables defined above. The SQF gives the latent outcome $G_{i j}$ when the endogenous variable $C_{i j}$ is fixed at a certain level and the disturbance is sampled independent of $C_{i j}$. Because of the endogeneity of competition, the SQF is a different function than the regular conditional quantile function $Q_{G}\left(\tau \mid C_{i j}, \mathbf{X}_{\mathbf{i}}, \mathbf{Z}_{\mathbf{j}}\right)$ that can be derived analogous to equation (5). In the presence of endogeneity however, $S_{G}\left(\tau \mid c_{i j}, \mathbf{x}_{\mathbf{i}}, \mathbf{z}_{\mathbf{j}}\right)$ cannot be directly estimated via a QR because the outcomes are latent, however the use of suitable instruments can overcome this limitation. In order to keep the notation simple, we will not discriminate between $Q_{G}$ and $S_{G}$.
} 
the inverse of the asymptotic variance $\sqrt{n}(\widehat{\gamma}(\tau)-\gamma(\tau))$. $W_{n}(\alpha)$ then becomes the Wald statistic for testing $\gamma(\alpha, \tau)=0$. Estimates for the parameters can then be written as $(\widehat{\alpha}(\tau), \widehat{\boldsymbol{\beta}}(\tau), \widehat{\boldsymbol{\delta}}(\tau))=(\widehat{\alpha}(\tau), \widehat{\boldsymbol{\beta}}(\widehat{\alpha}(\tau), \tau), \widehat{\boldsymbol{\delta}}(\widehat{\alpha}(\tau), \tau))$.

To find a practical way of estimating the IVQR model, consider that equation (10) can be stated as:

$$
G_{i j}-\alpha(\tau) C_{i j}=\mathbf{X}_{\mathbf{i}}\left(\boldsymbol{\beta}(\boldsymbol{\tau})+\boldsymbol{\beta}^{*}(\tau)\right)+\mathbf{Z}_{\mathbf{j}}\left(\boldsymbol{\delta}(\boldsymbol{\tau})+\boldsymbol{\delta}^{*}(\boldsymbol{\tau})\right)+\mathbf{I}_{\mathbf{i j}} \gamma(\boldsymbol{\tau}),
$$

with $\left(\boldsymbol{\beta}(\tau)+\boldsymbol{\beta}^{*}(\tau)\right)=\boldsymbol{\beta}(\tau)$ and $\left(\boldsymbol{\delta}(\tau)+\boldsymbol{\delta}^{*}(\tau)\right)=\boldsymbol{\delta}(\tau)$. In practice, the first step of IVQR consists of running the $\tau$-quantile regression of $G_{i j}-\alpha C_{i j}$ on $\mathbf{X}_{\mathbf{i}}, \mathbf{Z}_{\mathbf{j}}$ and $\mathbf{I}_{\mathbf{i j}}$ for a given grid of values of $\alpha$, thus obtaining the coefficients $\boldsymbol{\beta}(\alpha, \tau), \boldsymbol{\delta}(\alpha, \tau)$ and $\gamma(\alpha, \tau)$. In a second step, the $\widehat{\alpha}(\tau)$ is chosen which minimizes $W_{n}(\alpha)$. The coefficients of $\widehat{\beta}(\tau), \widehat{\delta}(\tau)$ are then implied by $\widehat{\beta}(\widehat{\alpha}(\tau), \tau), \widehat{\delta}(\widehat{\alpha}(\tau), \tau)$.

In what follows, estimates for the effect of competition on educational achievement and grade inflation are presented for the 5th to the 95th quantile (in steps of 5) using both QR and IVQR.

\subsection{QR and IVQR estimates}

The main results of both QR and IVQR are summarized in table 10 while figures 1 and 2 visualize the results.

The conventional QR results suggest that the effects of competition are positive for all schools except for those at the top of the grade distribution. These estimates are statistically significant for all but the 5th quantile and the top two deciles. Thus, contrary to what one might expect, it does not seem that the schools at the bottom of the grade distribution suffer from cream skimming by the schools at the top of the grade distribution and the IVQR results do nothing to change this impression. The IVQR estimates are mostly in the range of what QR suggests and - as is to be expected - standard errors are somewhat inflated.

From the QR results, competition seems to have the smallest restraining effect on grade inflation in the bottom part of the distribution of grade inflation. That is, schools which already practice little grade inflation ${ }^{25}$ do not react to competition by raising their local grading standards. It is the middle part of the distribution, starting at the 35th quantile that seems to react to competition by actually increasing their local grading standards. Obviously, one would have hoped for schools at the top of the grade inflation distribution to raise their standards the most as a reaction to competition. Still, the result clearly points out that schools that already practice heavy grade inflation do not try and attract

\footnotetext{
${ }^{25}$ While there are a few schools that award lower school grades than central exam grades, the 5 th percentile already practices grade inflation.
} 
students by further inflating their grades in response to competitive pressure. Once again, the IVQR results confirm the QR results.

\section{Conclusion}

This paper analyzed the effect of competition among secondary schools on achievement and grading standards in a setting that satisfies most of the criteria that are stipulated by school choice proponents. The Dutch empirical evidence is in line with theoretical predictions. Most of the empirical results support the notion of competition in the educational sector yielding beneficial results, i.e. leading to higher central exam scores while at the same time exerting a restraining effect on grade inflation. Competition in the Netherlands appears to be driven by catholic schools, while the availability of non-catholic alternatives doesn't seem to induce markedly higher educational attainment or lower levels of grade inflation. ${ }^{26}$ No evidence of endogeneity of competition could be found and quantile regression results clear concerns that competition may be detrimental to schools at the bottom of the grade distribution.

The placebo regressions suggest that sorting by ability and consequently peer effects is not what's driving these results. Suppose that school choice leads to perfect segregation by ability, i.e. all high-ability students leave for a catholic competitor. Those students remaining in the public sector would then attain considerably lower grades than the former mixed-ability student population. Then, using only non-catholic grades as the outcome variable could lead to the assumption that competition leads to lower achievement when this market is compared to one where no segregation occurs for lack of alternatives. Even when a rich set of controls is used, one couldn't completely disentangle the effect of sorting from the impact of competition. From the OLS results one could then hypothesize that in the Netherlands, the less able students leave for catholic schools. From the placebo regression results it seems, however, that catholic schools are not affected by competition at all. Competition does not seem to affect catholic grades, thus the competition effect net of sorting is supposedly still positive.

The bottom line of this paper is that competition as measured by the availability of catholic schools in close proximity seems to have positive effects on educational achievement as well the setting of standards. The latter result runs counter the tempting assumption that competition leads to a deterioration of standards - a claim that we can now clearly discard, at least in the Dutch context. There is, however, a need to look deeper into the mechanisms that drive the setting of standards at the local level. Also, so far only competition in the pre-university branch of education has been considered. Hence, it will be interesting to see whether these effects carry over to the lower school branches.

\footnotetext{
${ }^{26}$ Placebo regressions for the dependent variable grade inflation are not reported. Just as in the case of exam grades, they show no significant effects.
} 


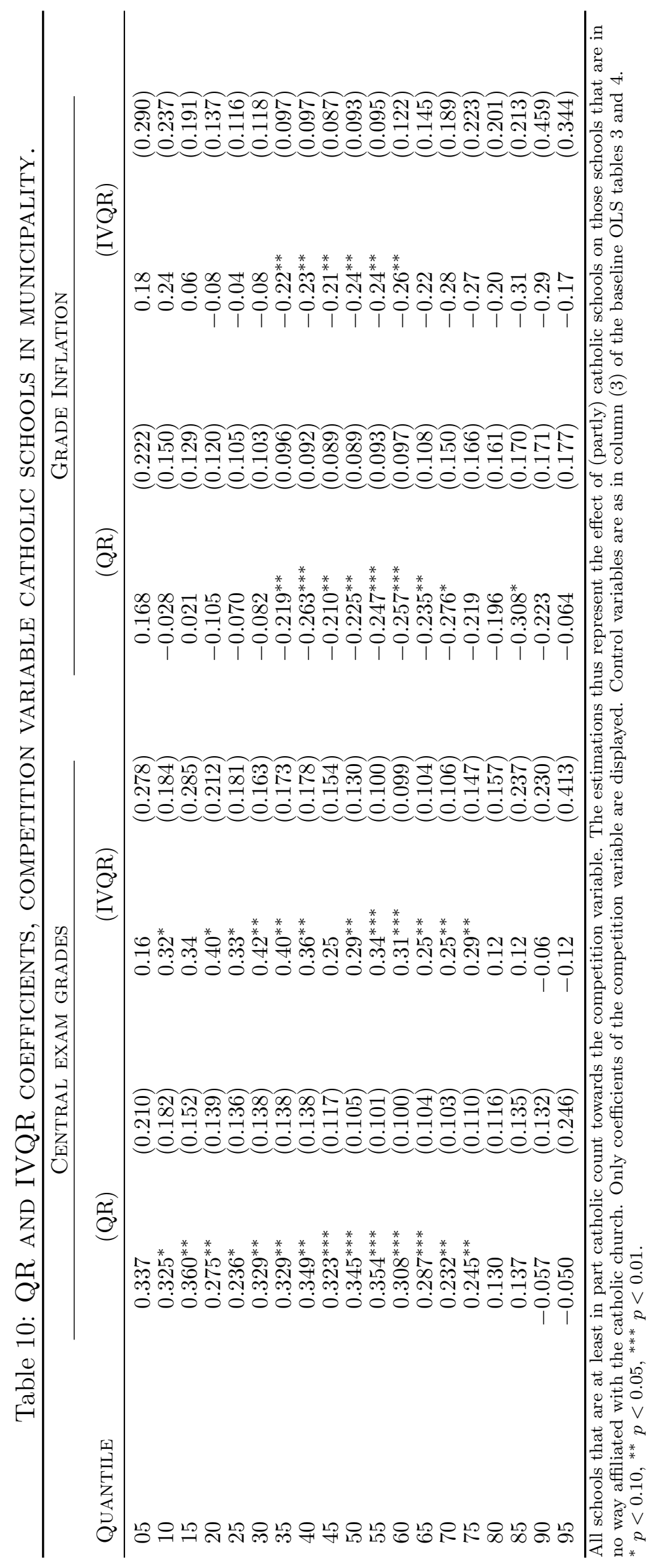



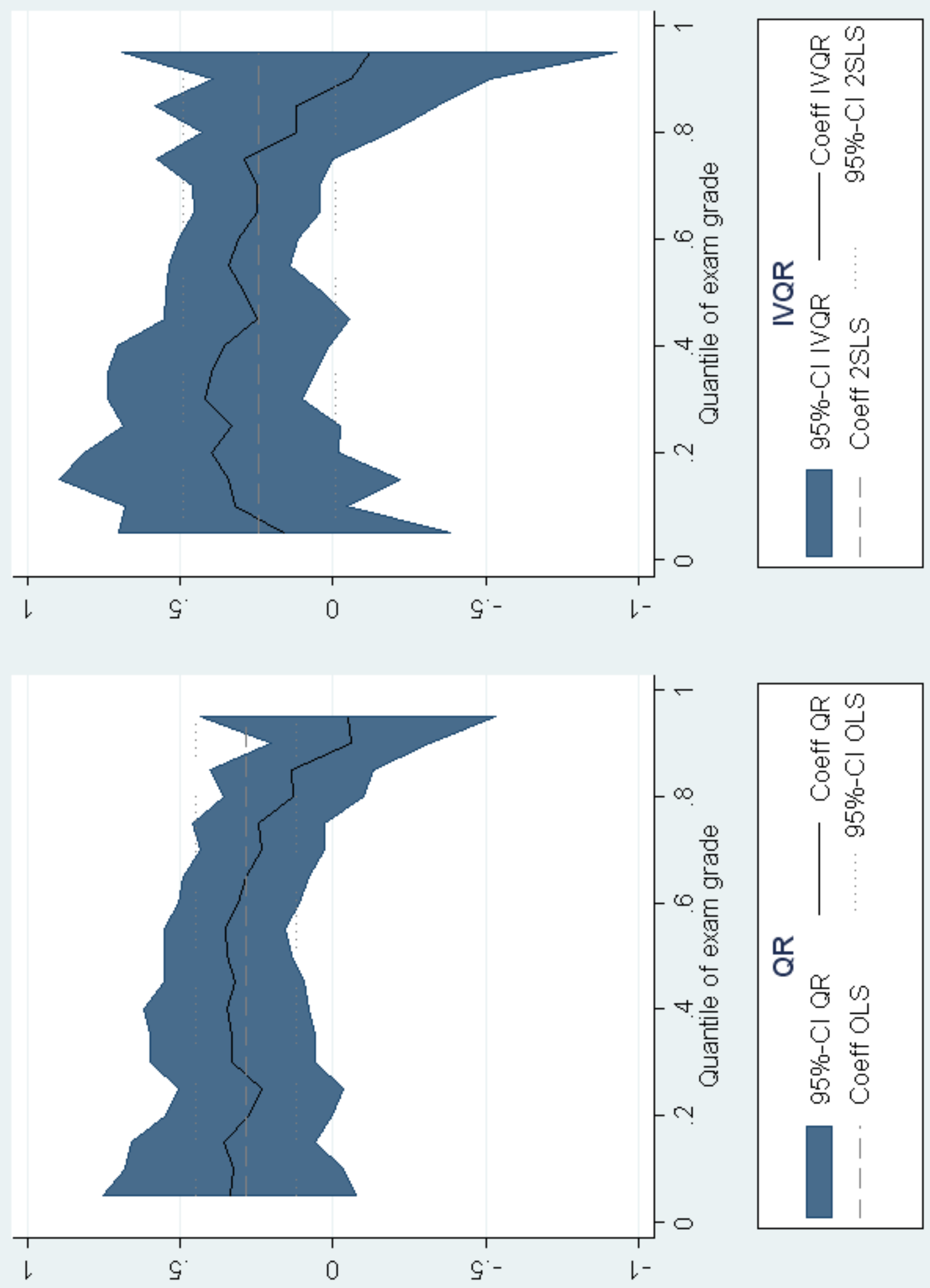

Figure 1: QR AND IVQR ESTIMATES, CENTRAL EXAM GRADES. 

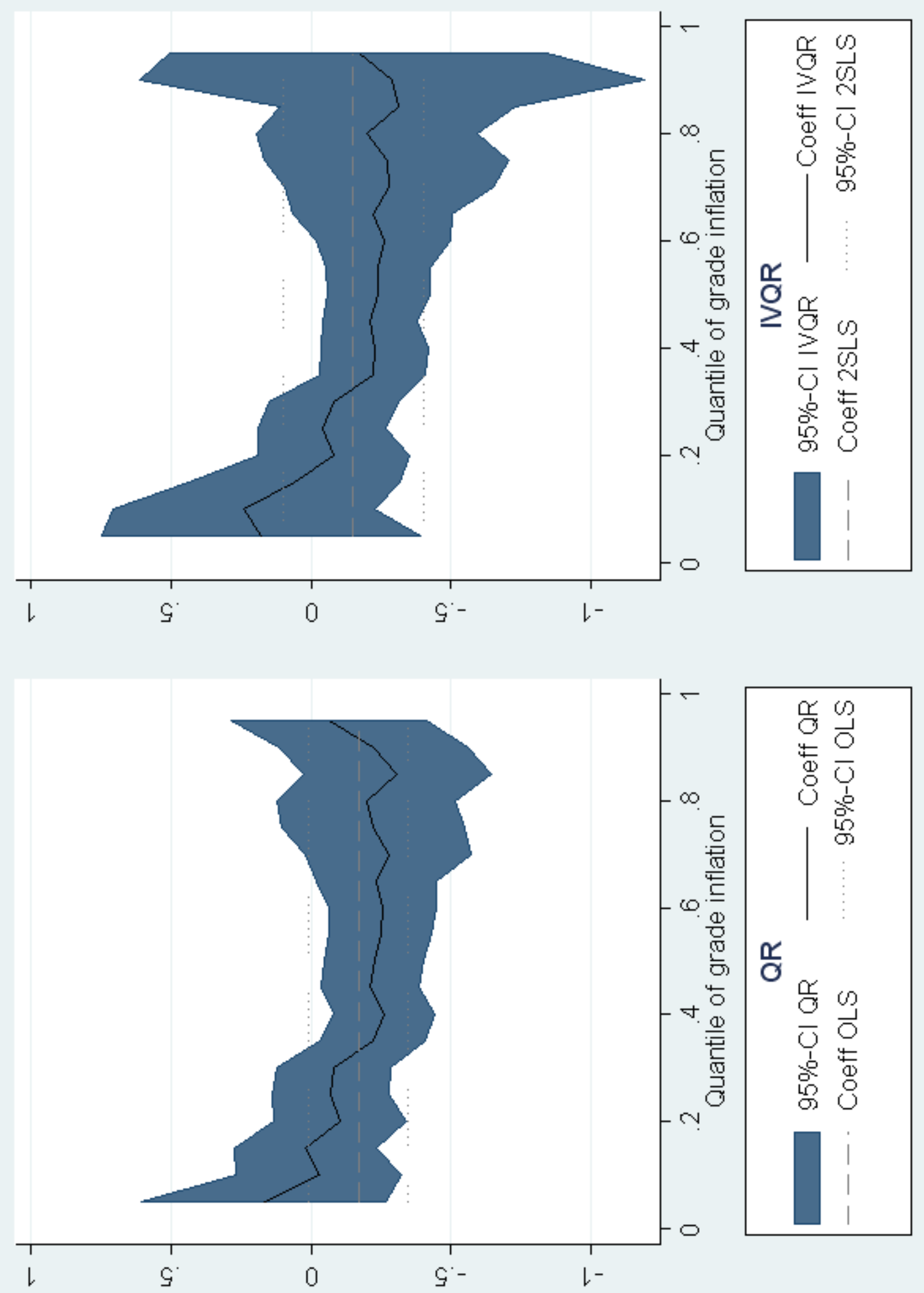

Figure 2: QR AND IVQR ESTIMATES, GRADE INFLATION. 


\section{References}

ÅHLin, A. (2003), Does school competition matter? Effects of a large-scale school choice reform on student performance, Uppsala University Working Paper Series 2.

BARrow, L. (2002), School choice through relocaton: Evidence from the Washington, D.C. area, Journal of Public Economics 86, 155-189.

Bayer, P., F.V. Ferreira, and McMillan, R. (2005), Tiebout sorting, social multipliers and the demand for school quality, NBER Working Paper W10871.

Belfield, C. and H. LEVIN (2002), The effects of competition on educational outcomes: A review of US evidence, Review of Educational Research 72, 279- 341.

BLACK, S. (1999), Do better schools matter? Parental valuation of elementary education, The Quarterly Journal of Economics 114, 577-599.

Borland, M. and R. Howsen (1993), On the determination of the critical level of market concentration in education, Economics of Education Review 12, 165-169.

Bradley, S., G. Johnes and J. Millington (1999), School Choice, Competition and the Efficiency of Secondary Schools in England. Lancaster University Management School Working Paper 1999/003.

Brasington, D. (2005), Public and Private School Competition: The Spatial Education Production Function, Department of Economics Working Paper Series, Working Paper 2005-09, Louisiana State University.

Chernozhukov, V. (2005), Inference for Extremal Conditional Quantile Models, with an Application to Birthweights, mimeo.

Chernozhukov, V. and C. Hansen (2005), An IV Model of Quantile Treatment Effects, Econometrica, 73(1), 245-61.

Chernozhukov, V. and C. Hansen (2006), Instrumental Quantile Regression Inference for Structural and Treatment Effect Models, Journal of Econometrics, 132(2), 491525.

Chernozhukov, V. and C. Hansen (2007), Inference Approaches for Instrumental Variable Quantile Regression, Economics Letters, 95(2), 272-77.

Chernozhukov, V. and C. Hansen (2008), Instrumental Variable Quantile Regression: A Robust Inference Approach, Journal of Econometrics, 142(1), 379-98.

Centraal Bureau voor de Statistiek, Kerncijfers postcodegebieden 2003.

Centraal Bureau voor de Statistiek, Nederland regionaal, accessed via http://www.CBS.nl.

Cheshire, P. and S. Sheppard (2003), Capitalising the Value of Free Schools: The Impact of Supply Constraints and Uncertainty, ERSA conference papers ersa03p8, European Regional Science Association. 
DeE, T. (1998), Competition and the Quality of Public Schools, Economics of Education Review 17, 419-427.

Denessen, E., G. Driessena and P. Sleegers (2005), Segregation by choice? A study of group-specific reasons for school choice, Journal of Education Policy 20, $347-368(22)$.

Denessen, E., P. Sleegers and F. Smit (2001), Reasons for School Choice in the Netherlands and in Finland, National Center for the Study of Privatization in Education Occasional Paper 24, Columbia University.

De ViJlder, F. (2000), Dutch education: A closed or an open system? Or: The art of maintaining an open system responsive to its changing environment, http://www.oecd.org/dataoecd/1/33/1917370.pdf.

Doksum, K. (1974), Empirical probability plots and statistical inference for nonlinear models in the two-sample case, Annals of Statistics, 2, 267-277.

Dronkers, J. (1995), The existence of parental choice in the Netherlands, Educational Policy 9, 227-243.

Dronkers, J. (2004), Do public and religious schools really differ? Assessing the European evidence, in: Wolf, P.J. and Macedo, S. (Eds.), Educating Citizens: International Perspectives on Civic Values and School Choice, Brookings Institution Press, Washington DC, 287-314.

Friedman, M. (1955), The role of government in education, in: Robert A. Solo (Hrsg.), Economics and the Public Interest, Rutgers University Press, New Brunswick, N.J, 127-134.

Geller, C., D. Sjoquist and M. Walker(2006), The Effect of Private School Competition on Public School Performance in Georgia, Public Finance Review 34, 4-32.

Gibbons, S. and O. Silva (2008), Urban Density and Pupil Achievement, Journal of Urban Economics 63(1), 631-650.

HAnusheK, E. and S. Rivkin (2003), Does public school competition affect teacher quality, in: Hoxby, C. (Hrsg.), The Economics of School Choice, University of Chicago Press, 23-47.

Himmler, O. and R. Schwager (2007), Double Standards in Educational Standards Are Disadvantaged Students being graded more leniently?, ZEW Discussion Paper 07-016.

HoxBy, C. (1994), Do private schools provide competition for public schools?, NBER Working Papers 4978.

HoxBy, C. (2000), Does competition among public schools benefit students and taxpayers? The American Economic Review 90, 1209-1239. 
Hsien, C.-T. and M. Urquiola (2006), The effects of generalized school choice on achievement and stratification: Evidence from Chile's voucher program, Journal of Public Economics 90, 1477-1503.

InSPECTIE VAN HET ONDERWIJS, Kwaliteitskaart Voortgezet Onderwijs, uitgaven 19982004, Steinmetz Archief, Amsterdam.

JEPSEn, C. (1999), The effects of private school competition on student achievement, Northwestern University Working Paper 99.

KASKI, Institute for Applied Research on Religion of the Radboud University Nijmegen, supplied data on catholic population by postcode.

Koenker, R. and G. W. Bassett (1978), Regression quantiles, Econometrica, 46, 33-50.

Levin, J. (2004), Differences in Educational Production Between Dutch Public and Religious Schools, National Center for the Study of Privatization in Education Occasional Paper 93, Columbia University.

Marlow, M. (1997), Public education supply and student performance, Applied Economics 29, 617-26.

Marlow, M. (1999), Spending, school structure, and public education quality, Economics of Education Review 19, 89-106.

Martinez-Vazquez, J., and B. Seaman (1985), Private schooling and the Tiebout hypothesis, Public Finance Quarterly 13, 293-318.

Ministerie van OnderwiJs Cultuur en Wetenschappen, Onderwijs in Cijfers 2003.

PAtrinos, H. (2002), Private education provision and public finance: The Netherlands as a possible model, NCSPE Occasional Paper No. 59.

Ritzen, J., J. van Dommelen and F. De ViJlder (1997), School finance and school choice in the Netherlands, Economics of Education Review 16, 329-335.

Rothstein, J. (2007), Does Competition Among Public Schools Benefit Students and Taxpayers? A Comment on Hoxby (2000), American Economic Review, 97(5), 20262037.

Sander, W. (1999), Private Schools and Public School Achievement, The Journal of Human Resources 34, 697-709.

SAndström, M. and F. Bergström (2005), School vouchers in practice: competition will not hurt you, Journal of Public Economics 89, 351-380.

Sociaal en Cultureel Planbureau, Statusscores postcodegebieden 2002.

Tiebout, C. (1956), A pure theory of local expenditures, Journal of Political Economy 64, 416-424. 
Walford, G. (2000), Funding for private schools in England and the Netherlands. Can the piper call the tune?, NCSPE Occasional Paper No. 8.

Weimer, D. and M. Wolkoff (2001), School performance and housing values: Using non-contiguous district and incorporation boundaries to identify school effects, National Tax Journal 54, 231-253.

ZANZIG, B. (1997), Measuring the impact of competition in local government education markets on the cognitive achievement of students, Economics of Education Review $16,431-441$.

\section{Appendix}

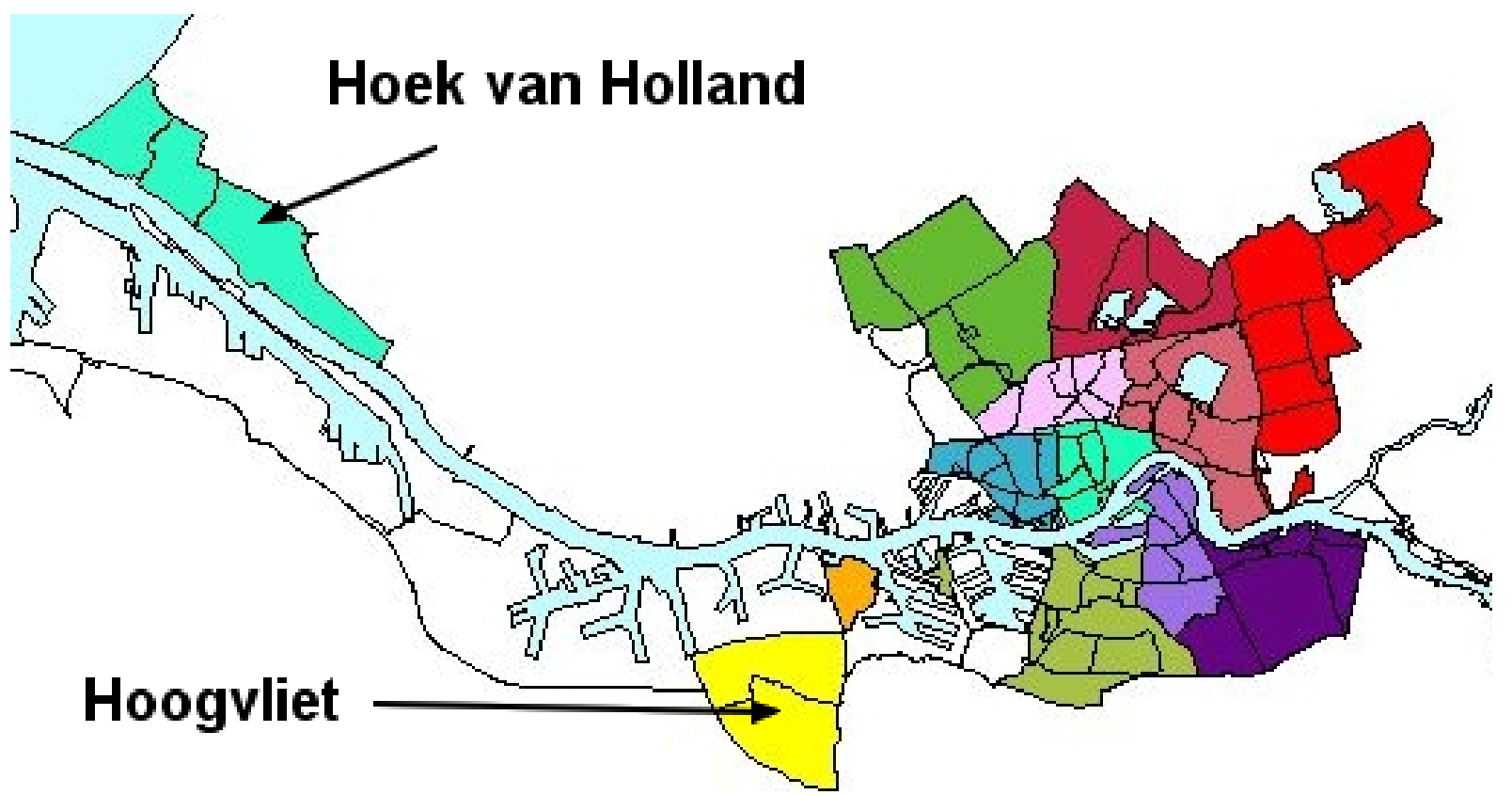

Rotterdam, deelgemeenten. Shaded areas are the Rotterdam boroughs. Source: Centrum voor Onderzoek en Statistiek, Rotterdam 
Table A-1: Summary STATistics, NON-CATHOLIC SCHOOLS.

\begin{tabular}{|c|c|c|c|c|c|}
\hline & $N$ & Mean & Std. Dev. & Min & Max \\
\hline Above advice \% & 575 & 22.22 & 17.95 & 0 & 100.00 \\
\hline Half above advice \% & 575 & 37.98 & 24.11 & 0 & 100.00 \\
\hline Minority (cumi) students \% & 616 & 5.44 & 9.82 & 0 & 78.94 \\
\hline Study cost recipients $\%$ & 615 & 28.07 & 11.33 & 8.67 & 100.00 \\
\hline Tracked in grade $1 \%$ & 591 & 34.32 & 34.59 & 0 & 100.00 \\
\hline Tracked in grade $2 \%$ & 584 & 61.14 & 36.21 & 0 & 100.00 \\
\hline Class size grade 1 & 597 & 25.28 & 2.64 & 16.00 & 32.00 \\
\hline Class size grade 2 & 587 & 25.22 & 2.65 & 11.00 & 31.00 \\
\hline Non-religious school dummy & 639 & 0.65 & 0.47 & 0 & 1.00 \\
\hline Number of students VWO (1000s) & 620 & 241.05 & 117.10 & 6.00 & 785.00 \\
\hline Number of students brin (1000s) & 614 & 1849.83 & 1104.02 & 97.00 & 5697.00 \\
\hline Short term debt $\%$ & 538 & 32.23 & 11.18 & 0 & 86.80 \\
\hline Long term debt $\%$ & 538 & 3.36 & 7.20 & 0 & 54.30 \\
\hline Staff growth \% & 608 & 2.84 & 5.70 & -25.50 & 30.50 \\
\hline Number of students growth $\%$ & 608 & 1.88 & 5.02 & -16.20 & 27.60 \\
\hline Part time staff $\%$ & 608 & 37.59 & 9.73 & 15.90 & 69.00 \\
\hline Quality of life & 639 & 0.03 & 1.07 & -2.74 & 3.52 \\
\hline Average income (1000 Euro) & 633 & 12.99 & 1.12 & 10.80 & 19.20 \\
\hline Population share school aged & 638 & 17.67 & 1.82 & 13.90 & 24.00 \\
\hline Pop. density $\left(1000 / \mathrm{km}^{2}\right)$ & 638 & 2.04 & 1.59 & 0.05 & 5.67 \\
\hline Land area $\left(\mathrm{km}^{2}\right)$ & 638 & 117.96 & 118.00 & 6.62 & 765.39 \\
\hline Number of catholics (1000s) & 638 & 22.59 & 25.76 & 0.22 & 108.48 \\
\hline
\end{tabular}

Table A-2: SUMmary STATISTICS, NON ROMAN-CATHOLIC SCHOOLS.

\begin{tabular}{|c|c|c|c|c|c|}
\hline & $N$ & Mean & Std. Dev. & Min & $\operatorname{Max}$ \\
\hline Above advice $\%$ & 659 & 22.49 & 17.70 & 0 & 100.00 \\
\hline Half above advice $\%$ & 659 & 38.16 & 24.03 & 0 & 100.00 \\
\hline Minority (cumi) students $\%$ & 710 & 5.47 & 9.95 & 0 & 78.94 \\
\hline Study cost recipients $\%$ & 708 & 28.18 & 11.77 & 8.67 & 100.00 \\
\hline Tracked in grade $1 \%$ & 683 & 33.74 & 34.13 & 0 & 100.00 \\
\hline Tracked in grade $2 \%$ & 675 & 61.31 & 35.90 & 0 & 100.00 \\
\hline Class size grade 1 & 689 & 25.24 & 2.66 & 16.00 & 32.00 \\
\hline Class size grade 2 & 678 & 25.20 & 2.62 & 11.00 & 301.00 \\
\hline Non-religious school dummy & 733 & 0.57 & 0.49 & 0 & 1.00 \\
\hline Number of students VWO (1000s) & 709 & 241.21 & 114.97 & 6.00 & 785.00 \\
\hline Number of students brin (1000s) & 708 & 1857.34 & 1070.33 & 97.00 & 5697.00 \\
\hline Short term debt $\%$ & 625 & 32.35 & 11.04 & 0 & 86.80 \\
\hline Long term debt \% & 625 & 3.49 & 7.50 & 0 & 54.30 \\
\hline Staff growth \% & 696 & 2.87 & 5.78 & -25.50 & 30.50 \\
\hline Number of students growth $\%$ & 700 & 1.86 & 5.14 & -16.20 & 35.50 \\
\hline Part time staff $\%$ & 696 & 37.31 & 9.55 & 15.90 & 69.00 \\
\hline Quality of life & 733 & 0.06 & 1.08 & -2.74 & 3.52 \\
\hline Average income (1000 Euro) & 721 & 12.98 & 1.12 & 10.80 & 19.20 \\
\hline Population share school aged & 729 & 17.72 & 1.87 & 13.90 & 24.10 \\
\hline Pop. density $\left(1000 / \mathrm{km}^{2}\right)$ & 729 & 1.99 & 1.58 & 0.05 & 5.67 \\
\hline Land area $\left(\mathrm{km}^{2}\right)$ & 729 & 118.78 & 119.92 & 6.62 & 765.39 \\
\hline Number of catholics (1000s) & 729 & 22.85 & 25.20 & 0.22 & 108.48 \\
\hline
\end{tabular}


Table A-3: First stage statistics, additional instrument.

\begin{tabular}{lcccc}
\hline & \multicolumn{2}{c}{$(1)$} & \multicolumn{2}{c}{$(2)$} \\
& \multicolumn{2}{c}{ (Partly) catholic } & \multicolumn{2}{c}{ Roman-catholic } \\
\hline Catholics in municip. (1000s) & $0.0921^{* * *}$ & $(0.0101)$ & $0.0513^{* * *}$ & $(0.0170)$ \\
Cath in municip. squared & $-0.0006^{* * *}$ & $(0.0001)$ & -0.0003 & $(0.0002)$ \\
Road network (km) & $0.0007^{* * *}$ & $(0.0002)$ & $0.0008^{*}$ & $(0.0004)$ \\
\hline F-test excluded instr. & $\mathrm{F}(3,140)=47.84$ & $\mathrm{~F}(3,153)=14.96$ \\
& $\mathrm{p}=0.000$ & $\mathrm{p}=0.000$ \\
partial $R^{2}$ excluded instr. & 0.63 & 0.43 \\
\hline$R^{2}$ & 0.83 & 0.66 \\
$N$ & 542 & 616 \\
\hline
\end{tabular}

Estimates are for 1st stage of 2SLS. Number of schools is the dependent variable of 1st stage. Estimates shown for the excluded instruments only. Control variables are as in column (3) of the baseline OLS tables 3 and 4 . Standard errors in parentheses allow for clustering by municipality.

* $p<0.10, * * p<0.05, * * * p<0.01$.

Table A-4: 2SLS CENTRAL EXAM, ADD'L INSTRUMENT

\begin{tabular}{|c|c|c|c|c|}
\hline \multirow[b]{2}{*}{ (Partly) catholic schools } & \multicolumn{2}{|c|}{$\begin{array}{c}(1) \\
\text { (Partly) catholic }\end{array}$} & \multicolumn{2}{|c|}{$\begin{array}{c}(2) \\
\text { Roman-catholic }\end{array}$} \\
\hline & $0.2459^{*}$ & $(0.133)$ & & \\
\hline Roman catholic schools & & & 0.1961 & $(0.166)$ \\
\hline Above advice $\%$ & $-0.0456^{* * *}$ & $(0.011)$ & $-0.0474^{* * *}$ & $(0.010)$ \\
\hline Half above advice $\%$ & $-0.0136^{*}$ & $(0.008)$ & $-0.0156^{* *}$ & $(0.008)$ \\
\hline Minority (cumi) students \% & $-0.0832^{* * *}$ & $(0.020)$ & $-0.0923^{* * *}$ & $(0.017)$ \\
\hline Study cost recipients $\%$ & $-0.0384^{* *}$ & $(0.019)$ & -0.0288 & $(0.018)$ \\
\hline Tracked in grade $1 \%$ & $0.0111^{* *}$ & $(0.004)$ & $0.0083^{*}$ & $(0.004)$ \\
\hline Tracked in grade $2 \%$ & -0.0007 & $(0.004)$ & 0.0002 & $(0.004)$ \\
\hline Class size grade 1 & $0.1465^{* * *}$ & $(0.047)$ & $0.1403^{* * *}$ & $(0.045)$ \\
\hline Class size grade 2 & -0.0101 & $(0.050)$ & -0.0230 & $(0.052)$ \\
\hline Non-religious school dummy & $-0.6703^{* *}$ & $(0.266)$ & $-0.4265^{*}$ & $(0.244)$ \\
\hline Number of students VWO (1000s) & 0.0379 & $(1.198)$ & 0.0492 & $(1.266)$ \\
\hline Number of students brin (1000s) & -0.0052 & $(0.120)$ & -0.0123 & $(0.118)$ \\
\hline Quality of life & -0.0759 & $(0.146)$ & -0.1402 & $(0.140)$ \\
\hline Average income (1000 Euro) & -0.1819 & $(0.139)$ & $-0.2497^{*}$ & $(0.135)$ \\
\hline Population share school aged & 0.0754 & $(0.076)$ & 0.0607 & $(0.064)$ \\
\hline Pop. density $\left(1000 / \mathrm{km}^{2}\right)$ & -0.0516 & $(0.095)$ & 0.0165 & $(0.085)$ \\
\hline Land area $\left(\mathrm{km}^{2}\right)$ & -0.0008 & $(0.001)$ & -0.0001 & $(0.001)$ \\
\hline Year 2003 & $0.4062^{* * *}$ & $(0.137)$ & $0.3877^{* * *}$ & $(0.136)$ \\
\hline Intercept & 64.3431 & $(2.761)$ & 65.6149 & $(2.658)$ \\
\hline & \multirow{2}{*}{\multicolumn{2}{|c|}{$\begin{array}{c}542 \\
0.325\end{array}$}} & \multirow{2}{*}{\multicolumn{2}{|c|}{$\begin{array}{c}616 \\
0.306\end{array}$}} \\
\hline adj. $R^{2}$ & & & & \\
\hline test of overid. restr. $\chi^{2}(2)$ & 0.016 & $(p=0.992)$ & 0.548 & $(p=0.760)$ \\
\hline
\end{tabular}




\section{CESifo Working Paper Series}

for full list see www.cesifo-group.org/wp

(address: Poschingerstr. 5, 81679 Munich, Germany, office@cesifo.de)

2613 Michael Melvin, Christian Saborowski, Michael Sager and Mark P. Taylor, Bank of England Interest Rate Announcements and the Foreign Exchange Market, April 2009

2614 Marie-Louise Leroux, Pierre Pestieau and Gregory Ponthiere, Should we Subsidize Longevity?, April 2009

2615 Ronald MacDonald, Lukas Menkhoff and Rafael R. Rebitzky, Exchange Rate Forecasters' Performance: Evidence of Skill?, April 2009

2616 Frederick van der Ploeg and Steven Poelhekke, The Volatility Curse: Revisiting the Paradox of Plenty, April 2009

2617 Axel Dreher, Peter Nunnenkamp, Hannes Öhler and Johannes Weisser, Acting Autonomously or Mimicking the State and Peers? A Panel Tobit Analysis of Financial Dependence and Aid Allocation by Swiss NGOs, April 2009

2618 Guglielmo Maria Caporale, Roman Matousek and Chris Stewart, Rating Assignments: Lessons from International Banks, April 2009

2619 Paul Belleflamme and Martin Peitz, Asymmetric Information and Overinvestment in Quality, April 2009

2620 Thomas Dohmen, Armin Falk, David Huffman and Uwe Sunde, Are Risk Aversion and Impatience Related to Cognitive Ability?, April 2009

2621 Yin-Wong Cheung and Xingwang Qian, The Empirics of China's Outward Direct Investment, April 2009

2622 Frédérique Bec and Christian Gollier, Assets Returns Volatility and Investment Horizon: The French Case, April 2009

2623 Ronnie Schöb and Marcel Thum, Asymmetric Information Renders Minimum Wages Less Harmful, April 2009

2624 Martin Ruf and Alfons J. Weichenrieder, The Taxation of Passive Foreign Investment Lessons from German Experience, April 2009

2625 Yao Li, Borders and Distance in Knowledge Spillovers: Dying over Time or Dying with Age? - Evidence from Patent Citations, April 2009

2626 Jim Malley and Ulrich Woitek, Technology Shocks and Aggregate Fluctuations in an Estimated Hybrid RBC Model, April 2009

2627 Jin Cao and Gerhard Illing, Endogenous Systemic Liquidity Risk, April 2009 
2628 Thiess Buettner and Bjoern Kauder, Revenue Forecasting Practices: Differences across Countries and Consequences for Forecasting Performance, April 2009

2629 Håkan Selin, The Rise in Female Employment and the Role of Tax Incentives - An Empirical Analysis of the Swedish Individual Tax Reform of 1971, April 2009

2630 Nick Johnstone and Ivan Hascic, Environmental Policy Design and the Fragmentation of International Markets for Innovation, April 2009

2631 Spiros Bougheas, Richard Kneller and Raymond Riezman, Optimal Education Policies and Comparative Advantage, April 2009

2632 Jay Pil Choi and Heiko Gerlach, Multi-Market Collusion with Demand Linkages and Antitrust Enforcement, April 2009

2633 Thor O. Thoresen, Income Mobility of Owners of Small Businesses when Boundaries between Occupations are Vague, April 2009

2634 Guido Schwerdt and Amelie C. Wuppermann, Is Traditional Teaching really all that Bad? A Within-Student Between-Subject Approach, April 2009

2635 Kurt R. Brekke, Luigi Siciliani and Odd Rune Straume, Hospital Competition and Quality with Regulated Prices, April 2009

2636 Peter Diamond, Taxes and Pensions, April 2009

2637 Shoshana Grossbard, How "Chicagoan” are Gary Becker's Economic Models of Marriage?, May 2009

2638 Roland Strausz, Regulatory Risk under Optimal Incentive Regulation, May 2009

2639 Holger Zemanek, Ansgar Belke and Gunther Schnabl, Current Account Imbalances and Structural Adjustment in the Euro Area: How to Rebalance Competitiveness, May 2009

2640 Harald Hau and Marcel Thum, Subprime Crisis and Board (In-)Competence: Private vs. Public Banks in Germany, May 2009

2641 Martin Halla, Mario Lackner and Friedrich G. Schneider, An Empirical Analysis of the Dynamics of the Welfare State: The Case of Benefit Morale, May 2009

2642 Balázs Égert, Infrastructure Investment in Network Industries: The Role of Incentive Regulation and Regulatory Independence, May 2009

2643 Christian Gollier, Expected Net Present Value, Expected Net Future Value, and the Ramsey Rule, May 2009

2644 Sören Blomquist and Håkan Selin, Hourly Wage Rate and Taxable Labor Income Responsiveness to Changes in Marginal Tax Rates, May 2009 
2645 Dominique Demougin, Oliver Fabel and Christian Thomann, Implicit vs. Explicit Incentives: Theory and a Case Study, May 2009

2646 Francesco C. Billari and Vincenzo Galasso, What Explains Fertility? Evidence from Italian Pension Reforms, May 2009

2647 Kjell Arne Brekke, Karen Evelyn Hauge, Jo Thori Lind and Karine Nyborg, Playing with the Good Guys - A Public Good Game with Endogenous Group Formation, May 2009

2648 Guglielmo Maria Caporale and Luis A. Gil-Alana, Multi-Factor Gegenbauer Processes and European Inflation Rates, May 2009

2649 Henning Bohn, A Static Model for Voting on Social Security, May 2009

2650 Markus Haavio and Kaisa Kotakorpi, The Political Economy of Sin Taxes, May 2009

2651 Augusto de la Torre, María Soledad Martínez Pería and Sergio L. Schmukler, Drivers and Obstacles to Banking SMEs: The Role of Competition and the Institutional Framework, May 2009

2652 Tobias Lindhe and Jan Södersten, Dividend Taxation, Share Repurchases and the Equity Trap, May 2009

2653 Assaf Razin and Edith Sand, Migration-Regime Liberalization and Social Security: Political-Economy Effect, May 2009

2654 Yin-Wong Cheung and Hiro Ito, A Cross-Country Empirical Analysis of International Reserves, May 2009

2655 Bart Cockx and Bruno Van der Linden, Flexicurity in Belgium. A Proposal Based on Economic Principles, May 2009

2656 Michael Melvin, Lukas Menkhoff and Maik Schmeling, Exchange Rate Management in Emerging Markets: Intervention via an Electronic Limit Order Book, May 2009

2657 Susanne Neckermann, Reto Cueni and Bruno S. Frey, What is an Award Worth? An Econometric Assessment of the Impact of Awards on Employee Performance, May 2009

2658 Steven Brakman, Harry Garretsen and Charles van Marrewijk, Economic Geography within and between European Nations: The Role of Market Potential and Density across Space and Time, May 2009

2659 Giovanni Facchini and Cecilia Testa, Reforming Legislatures: Is one House better than two?, May 2009

2660 Carsten Kowalczyk and Raymond Riezman, Trade Agreements, May 2009 
2661 Oliver Falck, Stephan Heblich and Elke Luedemann, Identity and Entrepreneurship, May 2009

2662 Christian Lessmann and Gunther Markwardt, One Size Fits All? Decentralization, Corruption, and the Monitoring of Bureaucrats, May 2009

2663 Felix Bierbrauer, On the Legitimacy of Coercion for the Financing of Public Goods, May 2009

2664 Alessandro Cigno, Agency in Family Policy: A Survey, May 2009

2665 Claudia M. Buch and Christian Pierdzioch, Low Skill but High Volatility?, May 2009

2666 Hendrik Jürges, Kerstin Schneider, Martin Senkbeil and Claus H. Carstensen, Assessment Drives Learning: The Effect of Central Exit Exams on Curricular Knowledge and Mathematical Literacy, June 2009

2667 Eric A. Hanushek and Ludger Woessmann, Schooling, Cognitive Skills, and the Latin American Growth Puzzle, June 2009

2668 Ourania Karakosta, Christos Kotsogiannis and Miguel-Angel Lopez-Garcia, Does Indirect Tax Harmonization Deliver Pareto Improvements in the Presence of Global Public Goods?, June 2009

2669 Aleksandra Riedl and Silvia Rocha-Akis, Testing the Tax Competition Theory: How Elastic are National Tax Bases in OECD Countries?, June 2009

2670 Dominique Demougin and Carsten Helm, Incentive Contracts and Efficient Unemployment Benefits, June 2009

2671 Guglielmo Maria Caporale and Luis A. Gil-Alana, Long Memory in US Real Output per Capita, June 2009

2672 Jim Malley and Ulrich Woitek, Productivity Shocks and Aggregate Cycles in an Estimated Endogenous Growth Model, June 2009

2673 Vivek Ghosal, Business Strategy and Firm Reorganization under Changing Market Conditions, June 2009

2674 Francesco Menoncin and Paolo M. Panteghini, Retrospective Capital Gains Taxation in the Real World, June 2009

2675 Thomas Hemmelgarn and Gaëtan Nicodème, Tax Co-ordination in Europe: Assessing the First Years of the EU-Savings Taxation Directive, June 2009

2676 Oliver Himmler, The Effects of School Competition on Academic Achievement and Grading Standards, June 2009 